Article

\title{
Sorbitol as a Polar Pharmacological Modifier to Enhance the Hydrophilicity of ${ }^{99 \mathrm{~m}}$ Tc-Tricarbonyl- Based Radiopharmaceuticals
}

\author{
Carolina Giammei ${ }^{1,2,3,+}$, Theresa Balber ${ }^{1,3,+}$, Katarina Benčurová ${ }^{1,3}$, Jens Cardinale ${ }^{1,3}$, \\ Neydher Berroterán-Infante 2,3(D), Marie Brandt ${ }^{1,3}$, Nedra Jouini 1,2,3 ${ }^{\text {, Marcus Hacker }}{ }^{3}$, \\ Markus Mitterhauser ${ }^{1,3}$ and Thomas L. Mindt 1,2,3,* \\ 1 Ludwig Boltzmann Institute Applied Diagnostics, General Hospital of Vienna, c/o Sekretariat \\ Nuklearmedizin, Währiger Gürtel 18-20, 1090 Vienna, Austria; carolina.giammei@lbiad.lbg.ac.at (C.G.); \\ theresa.balber@lbiad.lbg.ac.at (T.B.); katarina.bencurova@lbiad.lbg.ac.at (K.B.); \\ jens.cardinale@lbiad.lbg.ac.at (J.C.); marie.brandt@lbiad.lbg.ac.at (M.B.); nedra.jouini@lbiad.lbg.ac.at (N.J.); \\ markus.mitterhauser@meduniwien.ac.at (M.M.) \\ 2 Department of Inorganic Chemistry, Faculty of Chemistry, University of Vienna, Währinger Strasse 42, \\ 1090 Vienna, Austria; neydher.berroteraninfante@meduniwien.ac.at \\ 3 Department of Biomedical Imaging and Image-Guided Therapy, Division of Nuclear Medicine, Medical \\ University of Vienna, Währinger Gürtel 18-20, 1090 Vienna, Austria; marcus.hacker@meduniwien.ac.at \\ * Correspondence: thomas.mindt@lbiad.lbg.ac.at \\ + Authors contributed equally to the work.
}

Academic Editor: Fabio Zobi

Received: 12 May 2020; Accepted: 4 June 2020; Published: 9 June 2020

Abstract: The organometallic technetium-99m tricarbonyl core, $\left[{ }^{99 \mathrm{~m}} \mathrm{Tc}\right]\left[\mathrm{Tc}(\mathrm{CO})_{3}\left(\mathrm{H}_{2} \mathrm{O}\right)_{3}\right]^{+}$, is a versatile precursor for the development of radiotracers for single photon emission computed tomography (SPECT). A drawback of the ${ }^{99 \mathrm{~m}} \mathrm{Tc}$-tricarbonyl core is its lipophilicity, which can influence the pharmacokinetic properties of the SPECT imaging probe. Addition of polar pharmacological modifiers to ${ }^{99 \mathrm{~m}}$ Tc-tricarbonyl conjugates holds the promise to counteract this effect and provide tumor-targeting radiopharmaceuticals with improved hydrophilicities, e.g., resulting in a favorable fast renal excretion in vivo. We applied the "Click-to-Chelate" strategy for the assembly of a novel ${ }^{99 \mathrm{~m}}$ Tc-tricarbonyl labeled conjugate made of the tumor-targeting, modified bombesin binding sequence $\left[\mathrm{Nle}^{14}\right] \mathrm{BBN}(7-14)$ and the carbohydrate sorbitol as a polar modifier. The ${ }^{99 \mathrm{~m}} \mathrm{Tc}$-radiopeptide was evaluated in vitro with PC-3 cells and in Fox- $1^{\text {nu }}$ mice bearing PC-3 xenografts including a direct comparison with a reference conjugate lacking the sorbitol moiety. The glycated ${ }^{99 \mathrm{~m}} \mathrm{Tc}$-tricarbonyl peptide conjugate exhibited an increased hydrophilicity as well as a retained affinity toward the Gastrin releasing peptide receptor and cell internalization properties. However, there was no significant difference in vivo in terms of pharmacokinetic properties. In particular, the rate and route of excretion was unaltered in comparison to the more lipophilic reference compound. This could be attributed to the intrinsic properties of the peptide and/or its metabolites. We report a novel glycated (sorbitol-containing) alkyne substrate for the "Click-to-Chelate" methodology, which is potentially of general applicability for the development of ${ }^{99 \mathrm{~m}} \mathrm{Tc}$-tricarbonyl based radiotracers displaying an enhanced hydrophilicity.

Keywords: ${ }^{99 \mathrm{~m}} \mathrm{Tc}-$ tricarbonyl; bombesin; click-to-chelate; glycation; sorbitol; pharmacological modifier; hydrophilicity; radiolabeled peptides; SPECT 


\section{Introduction}

Radiolabeled peptides have become an indispensable tool in nuclear medicine for the diagnosis (imaging) and therapy of cancer. In the majority of cases, radioactive metals are used in this context. Application of radiometal complexes for the radiolabeling of peptides has the advantage that the metal is exchangeable and thus, both diagnostic and therapeutic probes become accessible depending on the radionuclide employed. This approach has been termed "theranostics" [1]. Different combinations of radiometals have been described in the literature for theranostic approaches [2], for example the matched pair of the group 7 transition metals technetium-99m ( $\gamma$-emitter for imaging) and rhenium-186/188 ( $\beta^{-}$-emitter for therapy) [3]. Technetium-99m $\left({ }^{99 m} \mathrm{Tc}\right)$ is considered the workhorse of nuclear medicine among the single photon emitting radionuclides for molecular imaging by SPECT due to its optimal physical properties $\left(t_{1 / 2}=6 \mathrm{~h}, \mathrm{E}_{\gamma}=140 \mathrm{keV}\right)$ and broad availability. After being eluted from the generator as pertechnetate, ${ }^{99} \mathrm{~m} \mathrm{Tc}(\mathrm{VII}) \mathrm{O}_{4}{ }^{-}$must be reduced to a lower oxidation state for the coordination with a chelating system. Among different reported ${ }^{99 \mathrm{~m}} \mathrm{Tc}$ precursors, also referred to as ${ }^{99 \mathrm{~m}} \mathrm{Tc}$ cores [4], the ${ }^{99 \mathrm{~m}} \mathrm{Tc}$-tricarbonyl core, $\left[{ }^{99 \mathrm{~m}} \mathrm{Tc}\right]\left[\mathrm{Tc}(\mathrm{CO})_{3}\left(\mathrm{H}_{2} \mathrm{O}\right)_{3}\right]^{+}$, is an interesting and promising candidate that can be readily prepared via the reduction of ${ }^{99 \mathrm{~m}} \mathrm{Tc}(\mathrm{VII})$ to ${ }^{99 \mathrm{~m}} \mathrm{Tc}(\mathrm{I}) \mathrm{using}$ commercial kits [5]. However, a potential drawback of the organometallic ${ }^{99 \mathrm{~m}}$ Tc-tricarbonyl precursor for radiometallation of (bio)molecules is its increased lipophilicity in comparison to other ${ }^{99 \mathrm{~m}} \mathrm{Tc}$-cores and radiometals, which can impact the pharmacokinetic profile of a tumor-targeting radiotracer. Lipophilic radiolabeled peptides can show hepatic uptake and slow hepatobiliary excretion instead of fast renal elimination, which is a favored characteristic of tumor-targeting imaging probes [6]. To overcome such issues, a number of radiolabeled peptides have been modified synthetically by conjugating polar pharmacological modifiers such as carboxylates [7-9], oligo- and polyethylene glycols $[10,11]$, or carbohydrates [12,13].

An elegant methodology to introduce a chelator for the ${ }^{99 \mathrm{~m}}$ Tc-tricarbonyl core into (bio)molecules is via the "Click-to-Chelate" approach (Figure 1) [6,14]. This strategy includes an application of the $\mathrm{Cu}(\mathrm{I})$-catalyzed azide-alkyne cycloaddition (CuAAC) $[15,16]$ by which an efficient tridentate chelator for the ${ }^{99 \mathrm{~m}} \mathrm{Tc}$-tricarbonyl core is formed and linked to (bio)molecules of interest while other moieties, e.g., carbohydrates, can be conjugated simultaneously [17]. We have previously applied this methodology to the assembly of a peptide conjugate comprising a modified analog of the binding sequence of the tumor-targeting peptide bombesin (BBN), namely [Nle $\left.{ }^{14}\right] \mathrm{BBN}(7-14)$, a ${ }^{99} \mathrm{~m}$ Tc-tricarbonyl complex and the carbohydrate glucuronic acid [18]. BBN is an attractive peptide for targeting the Gastrin-releasing peptide receptor (GRPR), which is overexpressed by a variety of tumors, including prostate and breast cancer [19]. The aim of the study was to enhance the hydrophilicity of the radiolabeled peptide and therefore favoring renal over hepatobiliary excretion. While the hydrophilicity of the glycated peptide conjugate was found substantially increased, we were surprised that it accumulated nevertheless to a higher degree in the spleen and liver in comparison to a more lipophilic BBN reference compound. We assumed that glucuronated, negatively charged metabolites of the radiolabeled peptide can be recognized by organic anion transporting polypeptides (OATPs), which are expressed in these organs [18].

We thus resorted to the use of other carbohydrates as pharmacological modifiers. Reduced acyclic carbohydrates lacking potentially charged functional groups appeared as a promising alternative. For example, sorbitol is used safely as an artificial sweetener in food products. Weinstein et al. have reported that $\left[{ }^{18} \mathrm{~F}\right]$ fluorodeoxysorbitol has potential as an infection imaging agent for positron emission tomography (PET) and does not accumulate in the spleen and liver [20]. Also Leamon et al. showed that sorbitol derivatives are promising polar moieties for preventing hepatic clearance of drugs [21]. We thus hypothesized that the sorbitol moiety might present an appropriate innocent pharmacological modifier for our purpose. Herein, we report the "Click-to-Chelate" synthesis, radiolabeling and in vitro and in vivo evaluation of a novel glycated (sorbitol-containing), ${ }^{99} \mathrm{~m}$ Tc-tricarbonyl labeled $\left[\mathrm{Nle}^{14}\right] \mathrm{BBN}(7-14)$ conjugate including a side-by-side comparison with a reference compound lacking the carbohydrate moiety. 


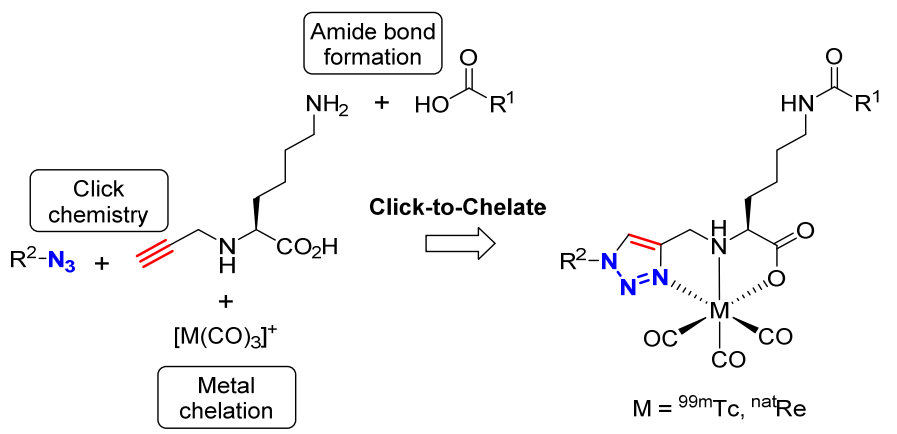

Figure 1. Assembly of ${ }^{99 \mathrm{~m}}$ Tc-labeled conjugates by “Click-to-Chelate".

\section{Results and Discussion}

\subsection{Syntheses}

The synthesis of a sorbitol containing CuAAC substrate for "Click-to-Chelate" started with the alkylation of 2,3;4,5-Di-O-isopropylidene D-glucitol (1) at the primary hydroxyl group with tert-butyl 4-bromobutanoate (2) by a reported 2-step procedure (Scheme 1) [22]. Removal of the acetonide groups of sorbitol derivative 3 followed by acetylation of the resulting pentaol 4 and subsequent cleavage of the tertBu-ester of intermediate 5 gave pentaacetate 6 in satisfying overall yield. Coupling of pentaacetate 6 to the $\mathrm{N}(\varepsilon)$-amine of the previously reported propargyl lysine derivative 7 [17] provided product $\mathbf{8}$ in good yield. Stepwise deprotection of compound $\mathbf{8}$ yielded first intermediate $\mathbf{9}$, which upon saponification with $\mathrm{NaOH}$ gave the desired glycated and deprotected alkyne synthon 10 for subsequent $\mathrm{CuAAC}$.

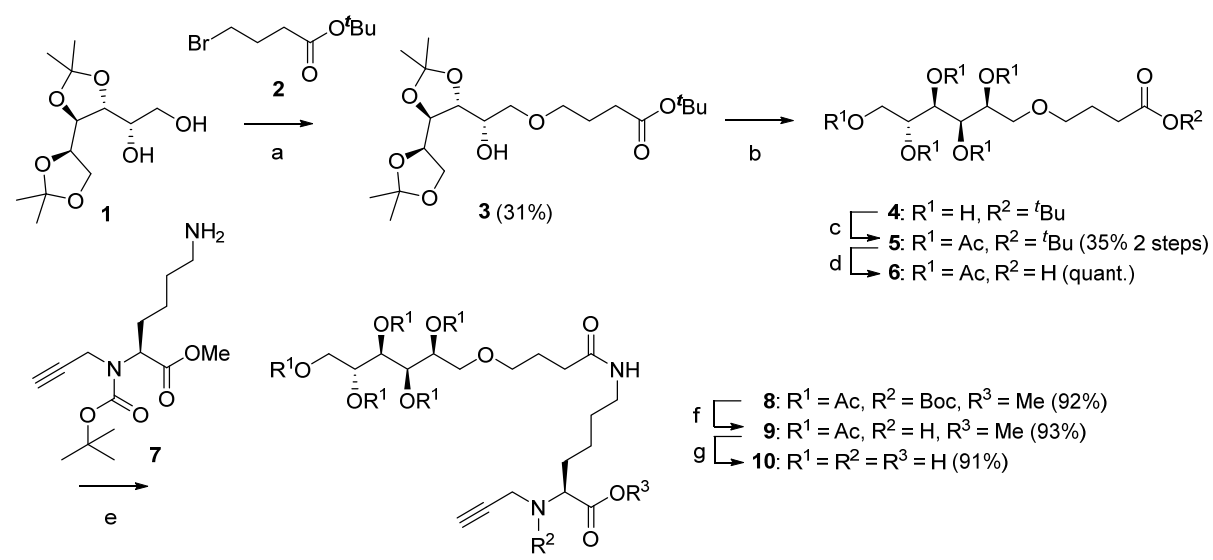

Scheme 1. Synthesis of $\mathrm{Cu}(\mathrm{I})$-catalyzed azide-alkyne cycloaddition (CuAAC) alkyne substrate 10. a) i) $\mathrm{Bu}_{2} \mathrm{SnO}$, toluene, Dean-Stark, reflux $24 \mathrm{~h}$, ii) tert-butyl 4-bromobutanoate (2), toluene, reflux, $24 \mathrm{~h}$; b) i) $\mathrm{AcOH}(80 \%), \mathrm{rt}, 18 \mathrm{~h}$, ii) $\mathrm{CHCl}_{3}, \mathrm{rt}, 18 \mathrm{~h}$; c) $\mathrm{Ac}_{2} \mathrm{O}$, pyridine, $\mathrm{CH}_{2} \mathrm{Cl}_{2}, \mathrm{rt}, 24 \mathrm{~h}$; d) $\mathrm{CH}_{2} \mathrm{Cl}_{2} / \mathrm{TFA}(3: 1), \mathrm{rt}$, 18 h; e) compound 7, BOP, DIPEA, $\mathrm{CH}_{2} \mathrm{Cl}_{2}, \mathrm{rt}, 2.5 \mathrm{~h}$; f) $\left.\mathrm{CH}_{2} \mathrm{Cl}_{2} / \mathrm{TFA}(3: 1), \mathrm{rt}, 3 \mathrm{~h} ; \mathrm{g}\right) \mathrm{MeOH} / \mathrm{THF}(1: 1)$, $\mathrm{NaOH}(1 \mathrm{M}), \mathrm{rt}, 13 \mathrm{~h}$.

Azido-bombesin derivative $\mathbf{1 1}$ was prepared manually by standard Fmoc solid phase peptide synthesis (SPPS) as previously described (Scheme 2A) [23]. In order to avoid potential interference of the radiometal complex with the tumor-targeting BBN vector, a spacer consisting of three $\beta$ Ala was introduced between the moieties. The peptide was cleaved from the resin, deprotected, and reacted in aqueous solution with alkyne derivative $\mathbf{1 0}$ using $\mathrm{Cu}(\mathrm{OAc})_{2}$ and Na-ascorbate. This yielded, after HPLC purification, the glycated peptide conjugate BBN-12. Reference compound BBN-13, identical in all aspects to the investigational compound BBN-12 but lacking the carbohydrate moiety, was prepared by the same chemistry as previously reported [23]. 
A

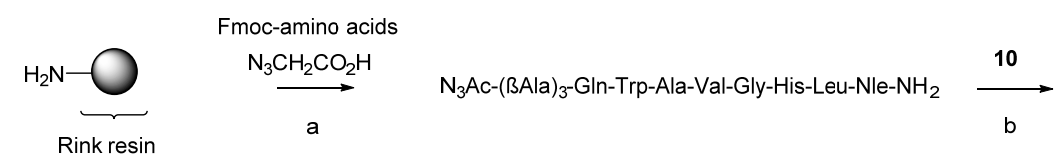

$\mathrm{N}_{3} \mathrm{Ac}(\mathrm{BAla})_{3}\left[\mathrm{NIe}^{14}\right] \mathrm{BBS}(7-14) 11(65 \%)$<smiles>CCCCCCOCCC(O)C(O)C(O)CO</smiles>

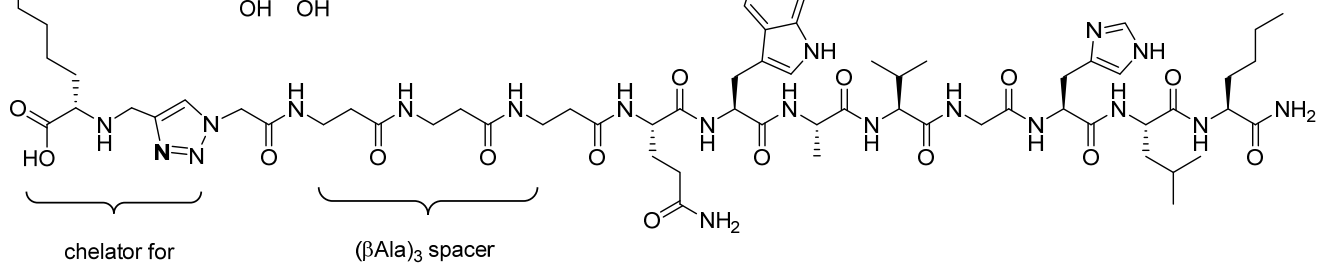

chelator for

${ }^{99 \mathrm{~m}}$ Tc-tricarbonyl

$(\beta \mathrm{Ala})_{3}$ space

B<smiles>CCNC(=O)CCNC(=O)CCNC(=O)Cn1cc(CN[C@@H](CCCCNC(C)=O)C(=O)O)nn1</smiles>
$\underset{\mathrm{d}}{\stackrel{\mathrm{c}}{\longrightarrow}}\left[{ }^{99 \mathrm{~m} \mathrm{Tc}} \mathrm{T}\left[\mathrm{Tc}(\mathrm{CO})_{3}(\mathbf{1 2})\right.\right.$

Glycated bombesin derivatie BBN-12 (30\%)<smiles></smiles>

Reference bombesin derivative BBN-13

Scheme 2. Peptide synthesis, CuAAC and (radio)metal complexation of sorbitol-containing peptide conjugate BBN-12 (A) and reference compound BBN-13 (B). a) SPPS: 1) Fmoc cleavage: 20\% piperidine in DMF, rt; 2) Elongation: Fmoc-amino acid or azido acetic acid $\left(\mathrm{N}_{3} \mathrm{CH}_{2} \mathrm{CO}_{2} \mathrm{H}\right)$ respectively, HATU, DIPEA, DMF, 2 h, rt; 3) Cleavage and deprotection: TFA/ $\mathrm{H}_{2} \mathrm{O} / \mathrm{PhOH} / \mathrm{Pr}_{3} \mathrm{SiH}$ : 92.5:2.5:2.5:2.5, 2 h, rt; b) for BBN-12: compound 10, $\mathrm{Cu}(\mathrm{OAc})_{2}, \mathrm{Na}$-ascorbate, $\mathrm{CH}_{3} \mathrm{CN} / \mathrm{H}_{2} \mathrm{O}, \mathrm{rt}, 13 \mathrm{~h}$; for $\mathrm{BBN}-13$ : see reference [23]; c) [ $\left.\left.{ }^{99 \mathrm{~m}} \mathrm{Tc}\right]\left[\mathrm{Tc}(\mathrm{CO})_{3}\left(\mathrm{H}_{2} \mathrm{O}\right)_{3}\right]^{+}, 100^{\circ} \mathrm{C}, 30 \mathrm{~min} ; \mathrm{d}\right)\left[\mathrm{N}(\mathrm{Et})_{4}\right]_{2}\left[\operatorname{Re}(\mathrm{CO})_{3} \mathrm{Br}_{3}\right], 100{ }^{\circ} \mathrm{C}, 1 \mathrm{~h}$.

\section{2. (Radio) Metal-Labeling and Characterization}

The tricarbonyl precursor $\left[{ }^{99 \mathrm{~m}} \mathrm{Tc}\right]\left[\mathrm{Tc}(\mathrm{CO})_{3}\left(\mathrm{H}_{2} \mathrm{O}\right)_{3}\right]^{+}$was prepared by adding $\left[{ }^{99 \mathrm{~m}} \mathrm{Tc}\right]\left[\mathrm{TcO}_{4}\right]^{-}$to the CRS kit (Center for Radiopharmaceutical Sciences, Paul Scherrer Institute, Villigen, Switzerland) and heating of the reaction mixture for $30 \mathrm{~min}$ at $100{ }^{\circ} \mathrm{C}$. The radiolabeling of both peptide conjugates BBN-12 and BBN-13 with [ $\left.{ }^{99 \mathrm{~m}} \mathrm{Tc}\right]\left[\mathrm{Tc}(\mathrm{CO})_{3}\left(\mathrm{H}_{2} \mathrm{O}\right)_{3}\right]^{+}$was carried out successfully either in a conventional heating block at $100^{\circ} \mathrm{C}$ for $30 \mathrm{~min}$ or in a microwave reactor at $120^{\circ} \mathrm{C}$ for $5 \mathrm{~min}$ (Scheme 2). The desired radiopeptides $\left[{ }^{99 \mathrm{~m}} \mathrm{Tc}\right]\left[\mathrm{Tc}(\mathrm{CO})_{3}(\mathrm{~L})\right](\mathrm{L}=\mathrm{BBN}-12,13)$ were obtained independent of the reaction conditions in a radiochemical yield and purity of $\geq 95 \%$ as determined by analytical $\gamma$-HPLC and $\gamma$-TLC.

For characterization of the ${ }^{99 \mathrm{~m}} \mathrm{Tc}$-labeled peptides, the non-radioactive analogous rhenium compounds [ $\left.{ }^{\text {nat }} \mathrm{Re}(\mathrm{CO})_{3}(\mathrm{~L})\right](\mathrm{L}=\mathbf{1 2}, 13)$ were prepared in $\mathrm{H}_{2} \mathrm{O}$ by reaction of conjugates $\mathrm{BBN}-12$ and BBN-13 with $\left[\mathrm{N}(\mathrm{Et})_{4}\right]_{2}\left[\operatorname{Re}(\mathrm{CO})_{3} \mathrm{Br}_{3}\right]$ at $100{ }^{\circ} \mathrm{C}$ for $1 \mathrm{~h}$ (Scheme 2) $[17,24]$. The products were purified by HPLC and analyzed by mass spectrometry. The comparison between the UV-HPLC $(\lambda=240 \mathrm{~nm})$ of the ${ }^{\text {nat }}$ Re-tricarbonyl peptides and the $\gamma$-HPLC of the corresponding ${ }^{99 \mathrm{~m}}$ Tc-tricarbonyl compounds confirmed their identity (for HPLC chromatograms and mass spectrometric analysis see SI, Figures S12-S15). 


\subsection{TLC Analytics}

In order to have an additional quality control with easy and rapid performance, a TLC system was developed to analyze the radiolabeled peptides conjugates (Table 1). The following retention factors $\left(R_{f}\right)$ were obtained for each analyzed sample and the radiochemical purity of the radiolabeled peptides was always in accordance to the results obtained using the $\gamma$-HPLC method. The impurities identified were either unreacted pertechnetate $(\sim 0.7 \%)$ and/or ${ }^{99}$ Tc-tricarbonyl precursor $(\sim 1.8 \%)$, which is also in accordance to the $\gamma$-HPLC results.

Table 1. TLC results for the quality control of the radiolabeled conjugates $\left[{ }^{99 \mathrm{~m}} \mathrm{Tc}\right]\left[\mathrm{Tc}(\mathrm{CO})_{3}(\mathrm{~L})\right](\mathrm{L}=\mathbf{1 2}$, 13; $n=2-3$ in duplicates). Silica gel $60 \mathrm{~F}_{254}$ aluminum plates were used as stationary phase and a mixture 95.5:0.5 of MeOH:HCl $6 \mathrm{M}$ as mobile phase. HPLC results are also reported for comparison.

\begin{tabular}{cccc}
\hline Compound[a] & \multicolumn{2}{c}{ TLC } & HPLC \\
\hline & $\mathbf{R}_{\mathbf{f}}$ & Radiochemical Purity (\%) & Radiochemical Purity (\%) \\
\hline$\left[{ }^{99 \mathrm{~m}} \mathrm{Tc}\right] \mathrm{TcO}_{4}{ }^{-}$ & 1.0 & 100 & 100 \\
$\left.{ }^{99 \mathrm{~m}} \mathrm{Tc}\right]\left[\mathrm{Tc}(\mathrm{CO})_{3}\left(\mathrm{H}_{2} \mathrm{O}\right)_{3}\right]^{+}$ & 0.0 & $>95$ & $>95$ \\
$\left.{ }^{99} \mathrm{~m} \mathrm{Tc}\right]\left[\mathrm{Tc}(\mathrm{CO})_{3}(\mathbf{1 3})\right]$ & $0.30-0.35$ & $94.4 \pm 0.2$ & $95 \pm 0.1$ \\
$\left.{ }^{99}{ }^{99} \mathrm{Tc}\right]\left[\mathrm{Tc}(\mathrm{CO})_{3}(\mathbf{1 2})\right]$ & $0.30-0.35$ & $93.1 \pm 0.5$ & $94 \pm 0.2$ \\
\hline
\end{tabular}

[a] Results from radiolabeling test experiments to demonstrate the conformity of the two methods for quality control; the products $(<95 \%$ purity) were not used for biological experiments.

\section{4. $\log D$}

For $\log \mathrm{D}$ analysis, the octanol/PBS partition coefficients of the ${ }^{99 \mathrm{~m}} \mathrm{Tc}$-tricarbonyl labeled BBN conjugates were determined at pH 7.4 utilizing the "shake-flask method" $[25,26]$. The $\log$ D value for the reference compound $\left[{ }^{99 \mathrm{~m}} \mathrm{Tc}\right]\left[\mathrm{Tc}(\mathrm{CO})_{3}(\mathrm{BBN}-13)\right]$ was $-0.54 \pm 0.04$ while for the glycated compound $\left[{ }^{99 \mathrm{~m}} \mathrm{Tc}\right]\left[\mathrm{Tc}(\mathrm{CO})_{3}(\mathbf{1 2})\right]$ it was $-1.26 \pm 0.16$ (Table 2). As expected, these measurements confirmed the increased hydrophilicity of the glycated ${ }^{99 \mathrm{~m}} \mathrm{Tc}$-labeled BBN conjugate due to the introduction of the sorbitol moiety. The physicochemical properties of the ${ }^{99 \mathrm{~m}} \mathrm{Tc}$-labeled peptides are summarized in Table 2.

Table 2. Results from in vitro experiments with ${ }^{99 \mathrm{~m}}$ Tc-radiopeptides.

\begin{tabular}{ccccc}
\hline Compound[a] & Total Cell Binding and Internalization \% AD/10 Cells[b] & $\mathbf{K}_{\mathbf{d}}[\mathbf{n M}][\mathbf{c}]$ & $\mathbf{B}_{\max }[\mathbf{n M}][\mathbf{c}]$ & $\operatorname{logD}[\mathbf{d}]$ \\
\hline$\left[{ }^{99 \mathrm{~m}} \mathrm{Tc}\right]\left[\mathrm{Tc}(\mathrm{CO})_{3}(\mathbf{1 3})\right]$ & $25.0 \pm 0.1$ & $3.7 \pm 1.0$ & $0.37 \pm 0.02$ & $-0.54 \pm 0.04$ \\
{$\left[{ }^{99 \mathrm{~m}} \mathrm{Tc}\right]\left[\mathrm{Tc}(\mathrm{CO})_{3}(\mathbf{1 2})\right]$} & $22.9 \pm 0.4$ & $21.3 \pm 4.6$ & $0.91 \pm 0.06$ & $-1.26 \pm 0.16$ \\
\hline
\end{tabular}

[a] Compound $\left.{ }^{99 \mathrm{~m}} \mathrm{Tc}\right]\left[\mathrm{Tc}(\mathrm{CO})_{3}(\mathbf{1 3})\right]$ was reported previously [23] and results were comparable. [b] Total cell bound and internalized fraction of $\left[{ }^{99 \mathrm{~m}} \mathrm{Tc}\right]\left[\mathrm{Tc}(\mathrm{CO})_{3}(\mathrm{~L})\right](\mathrm{L}=\mathbf{1 2}, \mathbf{1 3})$ after $1 \mathrm{~h}$. Results are normalized to $10^{6} \mathrm{PC}-3$ cells; values are the mean $\pm \mathrm{SD}(n=2-3$ in triplicate). [c] Determined by receptor saturation binding assay; values are the mean \pm SEM as calculated by GraphPad Prism 7 ( $n=2-3$ in triplicate). [d] Determined by the shake flask method; values are the mean $\pm \mathrm{SD}(n=3$, in triplicate).

\subsection{In Vitro Evaluation}

$\left[{ }^{99 \mathrm{~m}} \mathrm{Tc}\right]\left[\mathrm{Tc}(\mathrm{CO})_{3}(\mathbf{1 2})\right]$ was evaluated in vitro and compared with the reference compound $\left[{ }^{99 \mathrm{~m}} \mathrm{Tc}\right]\left[\mathrm{Tc}(\mathrm{CO})_{3}(\mathbf{1 3})\right]$. Receptor binding and cell internalization properties of the ${ }^{99 \mathrm{~m}} \mathrm{Tc}(\mathrm{CO})_{3}$-labeled BBN derivatives were investigated with GRPR expressing PC-3 cells ( $n=2-3$ in triplicate). Despite the slightly slower uptake kinetics of $\left[{ }^{99 \mathrm{~m}} \mathrm{Tc}\right]\left[\mathrm{Tc}(\mathrm{CO})_{3}(\mathbf{1 2})\right]$, both radiolabeled compounds $\left[{ }^{99 \mathrm{~m}} \mathrm{Tc}\right]\left[\mathrm{Tc}(\mathrm{CO})_{3}(\mathrm{~L})\right](\mathrm{L}=\mathbf{1 2}, 13)$ showed a comparable extent of cell binding and internalization: A plateau was reached after $1 \mathrm{~h}(22.9 \% \pm 0.4 \%$ and $25.0 \% \pm 0.1 \%$ of the applied radioactivity (AD) $/ 10^{6}$ cells, respectively; Table 2, Figure 2). The membrane bound fraction was less than $5 \%$ $\mathrm{AD} / 10^{6}$ cells for both compounds. The receptor-specific cell uptake was verified by incubating the cells with the radiopeptides in the presence of 1000 -fold excess of natural bombesin as blocking agent. For both radiolabeled peptides this resulted in a significant decrease of cellular binding and uptake $\left(<0.5 \% \mathrm{AD} / 10^{6}\right.$ cells). 


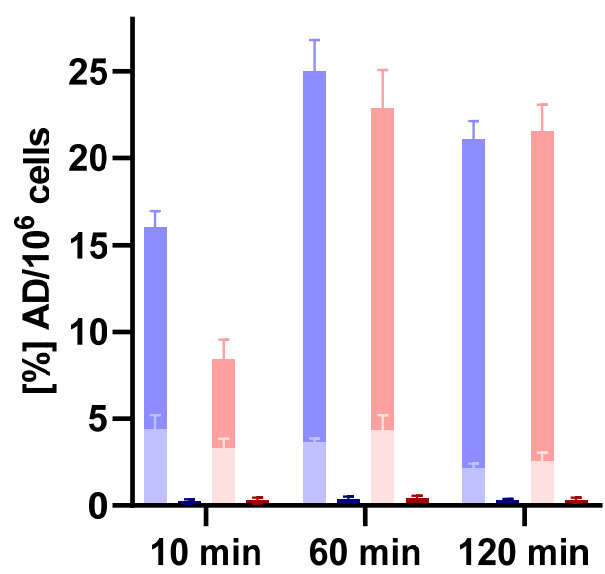

Membrane bound $\left[{ }^{99 \mathrm{~m}} \mathrm{Tc}\right]\left[\mathrm{Tc}(\mathrm{CO})_{3}(\mathbf{1 3})\right]$

Internalized $\left[{ }^{99 m} \mathrm{Tc}\right]\left[\mathrm{Tc}(\mathrm{CO})_{3}(\mathbf{1 3})\right]$

- Blocking $\left.{ }^{99 \mathrm{~m}} \mathrm{Tc}\right]\left[\mathrm{Tc}(\mathrm{CO})_{3}(\mathbf{1 3})\right]$

- Membrane bound $\left[{ }^{99 \mathrm{~m}} \mathrm{Tc}\right]\left[\mathrm{Tc}(\mathrm{CO})_{3}(\mathbf{1 2})\right]$

Internalized [ $\left.{ }^{99 \mathrm{~m}} \mathrm{Tc}\right]\left[\mathrm{Tc}(\mathrm{CO})_{3}(12)\right]$

Blocking $\left.{ }^{99 \mathrm{~m}} \mathrm{Tc}\right]\left[\mathrm{Tc}(\mathrm{CO})_{3}(\mathbf{1 2})\right]$

Figure 2. Cell binding and internalization of radiolabeled bombesin derivatives $\left[{ }^{99 \mathrm{~m}} \mathrm{Tc}\right]\left[\mathrm{Tc}(\mathrm{CO})_{3}(\mathbf{1 2})\right]$ and $\left[{ }^{99 \mathrm{~m}} \mathrm{Tc}\right]\left[\mathrm{Tc}(\mathrm{CO})_{3}(\mathbf{1 3})\right]$ using GRP-receptor expressing PC-3 cells; non-specific binding was determined with 1000-fold excess of $\mathrm{BBN}(1-14)$. Values are the mean $\pm \mathrm{SD}(n=2-3$ in triplicate) and data are normalized to $10^{6}$ cells per well.

The receptor affinity $\left(\mathrm{K}_{\mathrm{d}}\right)$ and maximum receptor occupancy $\left(\mathrm{B}_{\max }\right)$ were determined by receptor saturation assays using increasing amounts of the radiolabeled peptides (Figure 3). Receptor specificity of both compounds was demonstrated in the presence of a large excess of natural BBN. Higher values for $K_{d}$ and $B_{\max }$ were observed for $\left[{ }^{99 m} \mathrm{Tc}\right]\left[\mathrm{Tc}(\mathrm{CO})_{3}(\mathbf{1 2})\right]\left(\mathrm{K}_{d}=21.3 \pm\right.$ $\left.4.55 \mathrm{nM}, \mathrm{B}_{\max }=0.91 \pm 0.06 \mathrm{nM}\right)$ in comparison with the reference compound [ $\left.{ }^{99 \mathrm{~m}} \mathrm{Tc}\right]\left[\mathrm{Tc}(\mathrm{CO})_{3}(\mathbf{1 3})\right]$ $\left(\mathrm{K}_{\mathrm{d}}=3.7 \pm 1.0 \mathrm{nM}, \mathrm{B}_{\max }=0.37 \pm 0.02 \mathrm{nM}\right.$; Table 2$)$ [23]. Some variability in experimentally determined $K_{d}$ and $B_{\max }$ of structurally related radiolabeled peptides is not uncommon $[18,23,27]$, yet in this case somewhat surprising as we did not expect the sorbitol moiety to have an influence on these parameters; this in particular because the results of cell binding and internalization experiments were similar for both radiolabeled peptides (Figure 2). Differences in specific molar activities (MBq/mol) could account for this observation and cannot be entirely excluded even though both ${ }^{99 \mathrm{~m}}$ Tc-radiopeptides were prepared under identical conditions. Because this study aims at the investigation of differences in the pharmacokinetics of the radiopeptides (e.g., rate and route of excretion) rather than in tumor uptake, we continued with the evaluation of both compounds in vivo.

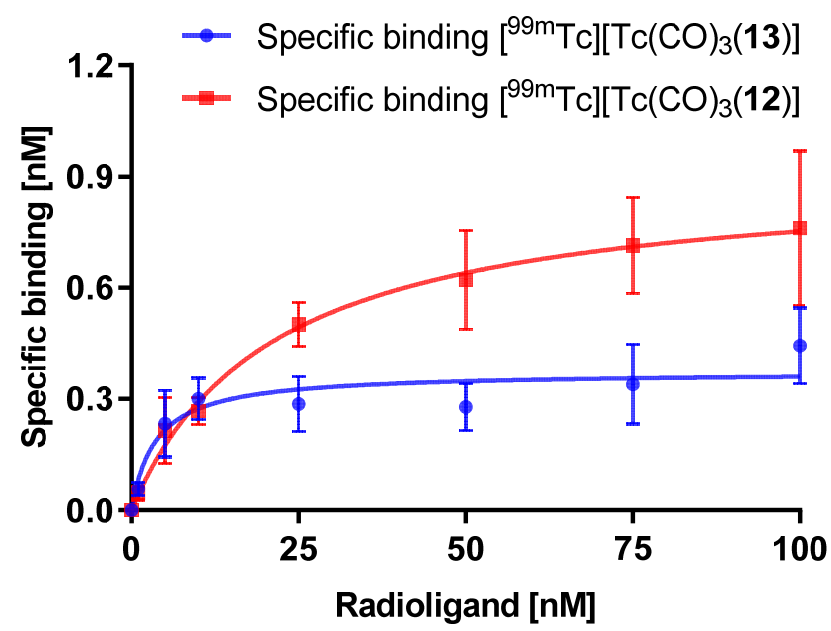

Figure 3. Results of receptor saturation experiments with radiolabeled bombesin (BBN) derivatives $\left[{ }^{99 \mathrm{~m}} \mathrm{Tc}\right]\left[\mathrm{Tc}(\mathrm{CO})_{3}(\mathbf{1 2})\right]$ and $\left[{ }^{99 \mathrm{~m}} \mathrm{Tc}\right]\left[\mathrm{Tc}(\mathrm{CO})_{3}(\mathbf{1 3})\right]$ using GRPR expressing PC-3 cells. $\mathrm{K}_{\mathrm{d}}$ and $\mathrm{B}_{\max }$ values were determined by nonlinear regression using GraphPad Prism 7. Data are the mean \pm SD $(n=2-3$ in triplicate) and normalized to $10^{6}$ cells per well. 


\subsection{In Vivo Evaluation}

Biodistribution studies were performed in nude mice bearing PC-3 tumor xenografts at $1 \mathrm{~h}$ post-injection (p.i.) of the radiotracers $(n=6$; Table 3, Figure 4). 2000-fold excess of BBN(1-14) was used as blocking agent and co-injected with the radiolabeled conjugate $\left[{ }^{99 \mathrm{~m}} \mathrm{Tc}\right]\left[\mathrm{Tc}(\mathrm{CO})_{3}(\mathbf{1 3})\right]$ or $\left[{ }^{99 \mathrm{~m}} \mathrm{Tc}\right]\left[\mathrm{Tc}(\mathrm{CO})_{3}(\mathbf{1 2})\right]$.

Table 3. Biodistribution data of radiolabeled peptide conjugates in nude mice bearing PC-3 xenografts.

\begin{tabular}{|c|c|c|c|c|}
\hline \multirow[t]{2}{*}{ Organ } & \multicolumn{2}{|c|}{$\left[{ }^{99 m} \mathrm{Tc}\right]\left[\mathrm{Tc}(\mathrm{CO})_{3}(13)\right](\% \mathrm{ID} / \mathrm{g})[\mathrm{b}]$} & \multicolumn{2}{|c|}{$\left[{ }^{99 m} \mathrm{Tc}\right]\left[\mathrm{Tc}(\mathrm{CO})_{3}(12)\right](\% \mathrm{ID} / \mathrm{g})[\mathrm{b}]$} \\
\hline & $1 \mathrm{~h}$ & $1 \mathrm{~h}$ Blocked & $1 \mathrm{~h}$ & $1 \mathrm{~h}$ Blocked \\
\hline Adrenal[a] & $1.85 \pm 0.67$ & $0.46 \pm 0.32$ & $5.34 \pm 1.85$ & $0.54 \pm 0.20$ \\
\hline Blood & $0.98 \pm 0.14$ & $1.03 \pm 0.41$ & $1.22 \pm 0.40$ & $1.24 \pm 0.34$ \\
\hline Bone & $0.31 \pm 0.07$ & $0.52 \pm 0.15$ & $0.44 \pm 0.28$ & $0.63 \pm 0.50$ \\
\hline Brain & $0.05 \pm 0.01$ & $0.06 \pm 0.02$ & $0.09 \pm 0.07$ & $0.07 \pm 0.04$ \\
\hline Colon[a] & $3.40 \pm 1.31$ & $0.39 \pm 0.18$ & $5.85 \pm 1.29$ & $0.34 \pm 0.11$ \\
\hline Heart & $0.32 \pm 0.02$ & $0.36 \pm 0.14$ & $0.50 \pm 0.23$ & $0.57 \pm 0.12$ \\
\hline Kidney & $3.58 \pm 0.70$ & $3.79 \pm 1.22$ & $4.32 \pm 0.97$ & $3.64 \pm 0.95$ \\
\hline Intestine[a] & $3.66 \pm 1.60$ & $1.11 \pm 0.07$ & $3.71 \pm 1.48$ & $0.69 \pm 0.32$ \\
\hline Liver & $3.31 \pm 0.60$ & $3.19 \pm 0.72$ & $2.75 \pm 0.74$ & $2.85 \pm 0.86$ \\
\hline Lung & $0.97 \pm 0.30$ & $1.03 \pm 0.38$ & $1.38 \pm 0.83$ & $1.69 \pm 0.69$ \\
\hline Muscle & $0.30 \pm 0.28$ & $1.94 \pm 1.08$ & $0.35 \pm 0.24$ & $0.29 \pm 0.04$ \\
\hline Pancreas[a] & $9.31 \pm 1.84$ & $0.52 \pm 0.13$ & $17.06 \pm 3.25$ & $0.60 \pm 0.20$ \\
\hline Spleen & $1.16 \pm 0.18$ & $0.64 \pm 0.13$ & $1.16 \pm 0.17$ & $0.79 \pm 0.32$ \\
\hline Stomach[a] & $3.79 \pm 1.53$ & $1.32 \pm 0.77$ & $3.03 \pm 0.88$ & $0.62 \pm 0.35$ \\
\hline Tumor[a] & $2.43 \pm 0.49$ & $0.68 \pm 0.17$ & $2.72 \pm 0.88$ & $0.67 \pm 0.14$ \\
\hline
\end{tabular}

[a] Gastrin-releasing peptide receptor (GRPR)-positive organs and tissues. [b] Results are given as the mean percentage of injected dose per gram of tissue $(\% \mathrm{ID} / \mathrm{g}) \pm \mathrm{SD} ; \mathrm{n}=5-6$ per group.

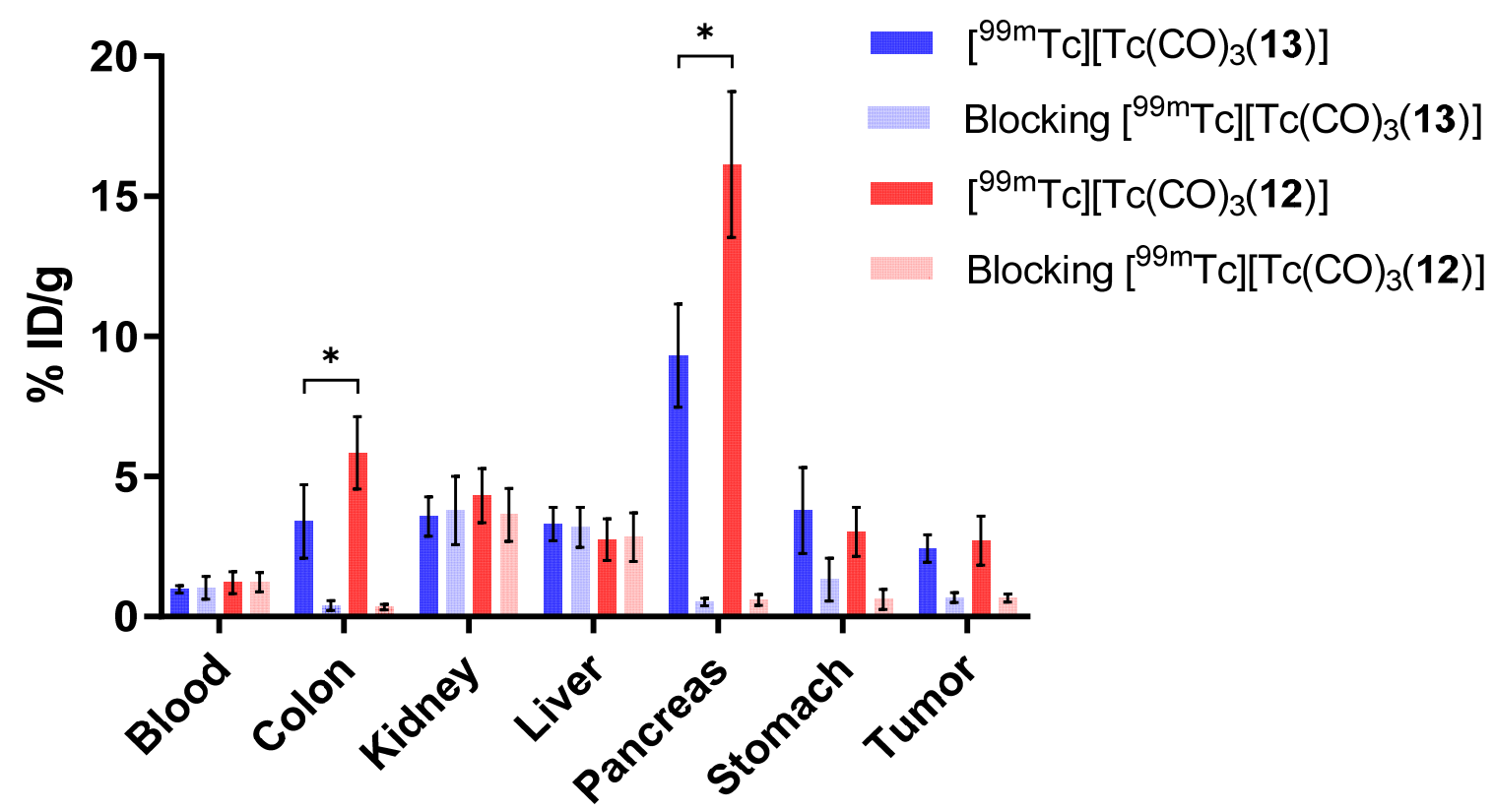

Figure 4. Biodistribution of radiolabeled bombesin derivatives $\left[{ }^{99 \mathrm{~m}} \mathrm{Tc}\right]\left[\mathrm{Tc}(\mathrm{CO})_{3}(\mathbf{1 2})\right]$ and $\left[{ }^{99 \mathrm{~m}} \mathrm{Tc}\right]\left[\mathrm{Tc}(\mathrm{CO})_{3}(\mathbf{1 3})\right]$ under blocking conditions in selected organs and tumors of mice bearing PC-3 cell xenografts at $1 \mathrm{~h}$ p.i. $(n=5-6)$; results are expressed as the percentage of injected dose per gram of tissue $(\% \mathrm{ID} / \mathrm{g})$; error bars indicate standard error of the mean; ${ }^{*}$ indicates $\alpha<0.05$.

The blood clearance of both radiopeptides $\left[{ }^{99 \mathrm{~m}} \mathrm{Tc}\right]\left[\mathrm{Tc}(\mathrm{CO})_{3}(\mathrm{~L})\right](\mathrm{L}=\mathbf{1 2}, \mathbf{1 3})$ was very fast with $0.98 \% \pm 0.14 \%$ and $1.22 \% \pm 0.40 \% \mathrm{ID} / \mathrm{g}$, respectively, already at $1 \mathrm{~h}$ p.i. Glycated $\left[{ }^{99 \mathrm{~m}} \mathrm{Tc}\right]\left[\mathrm{Tc}(\mathrm{CO})_{3}(\mathbf{1 2})\right]$ showed a significantly higher specific uptake than the reference compound $\left[{ }^{99 m} \mathrm{Tc}\right]\left[\mathrm{Tc}(\mathrm{CO})_{3}(\mathbf{1 3})\right]$ 
in the GRPR positive pancreas and in the colon. Very low accumulation of radioactivity was observed in receptor-negative tissues and organs (e.g., the uptake in muscle and bone was less than $0.5 \% \mathrm{ID} / \mathrm{g}$, Table 3). Blocking experiments resulted in a significant decrease of accumulation of radioactivity in GRPR-positive tumors and organs therefore demonstrating receptor specific uptake of the radiotracer ( $n=5$; Table 3, Figure 4). No significant differences in tumor uptake were observed as expected based on the in vitro cell binding and internalization experiments (Figure 2, Table 2). Despite glycation, the pharmacokinetics of $\left[{ }^{99 \mathrm{~m}} \mathrm{Tc}\right]\left[\mathrm{Tc}(\mathrm{CO})_{3}(\mathbf{1 2})\right]$ was not significantly altered in comparison to $\left[{ }^{99 \mathrm{~m}} \mathrm{Tc}\right]\left[\mathrm{Tc}(\mathrm{CO})_{3}(\mathbf{1 3})\right]$ and the enhanced renal excretion and lowered uptake in the liver was not as pronounced as expected. Therefore, the glycated radiopeptide did not perform significantly better in vivo. Nevertheless, as hypothesized, $\left[{ }^{99 \mathrm{~m}} \mathrm{Tc}\right]\left[\mathrm{Tc}(\mathrm{CO})_{3}(\mathbf{1 2})\right]$ bearing a sorbitol moiety did not show a pronounced accumulation in liver and spleen compared to the previously published glucuronated BBN derivative [18].

\section{Materials and Methods}

Caution: ${ }^{99 \mathrm{~m}} \mathrm{Tc}$ is a $\gamma$-emitter $(140 \mathrm{keV})$ with a half-life of $6.01 \mathrm{~h}$. All reactions involving ${ }^{99 \mathrm{~m}} \mathrm{Tc}$ were performed in a laboratory approved for the handling of radionuclides and appropriate safety procedures were followed at all times to prevent contamination.

\subsection{General Procedures}

Solvents and all other chemicals of at least of synthesis grade were purchased from B. Braun, Sigma-Aldrich, and Bachem. Buffers and stock solutions were prepared using Millipore water. $\left[{ }^{99 \mathrm{~m}} \mathrm{Tc}\right] \mathrm{NaTcO}_{4}$ was eluted from an Ultra-TechneKow or TEKCIS ${ }^{99} \mathrm{Mo} /{ }^{99} \mathrm{~m} \mathrm{Tc}$ generator. The precursor $\left[{ }^{99 \mathrm{~m}} \mathrm{Tc}\right]\left[\mathrm{Tc}(\mathrm{CO})_{3}\left(\mathrm{H}_{2} \mathrm{O}\right)_{3}\right]^{+}$was prepared by using the CRS kit for ${ }^{99 \mathrm{~m}} \mathrm{Tc}$-tricarbonyl (Center for Radiopharmaceutical Sciences, Paul Scherrer Institute, Villigen, Switzerland). The radiolabeling of the peptides was performed with a Biotage ${ }^{\circledR}$ Initiator+ microwave using a 200-500 $\mu \mathrm{L}$ glass reactor or with a heating block in $1.5 \mathrm{~mL}$ LoProtein bind Eppendorf vessels. HPLC analyses were carried out with an Agilent system (Vienna, Austria) equipped with Autosampler Agilent 1100 Series, Iso Pump (Isocratic Pump) Agilent 1200 Series G1310A, UV-Monitor Agilent 1200 Series G1314B Variable Wavelength Detector (VWD) and Radioactivity Detector Elysia Raytest Gabi Star. Data acquisition and gradient control were performed using GINA StarTM, version 5.9. HPLC solvents were $0.1 \%$ TFA in $\mathrm{H}_{2} \mathrm{O}(\mathrm{A})$ and $\mathrm{MeCN}$ (B). Quality control of the radiometal labeled peptide was performed using a C12 Phenomenex Jupiter column ( $4 \mathrm{u}$ Proteo $90 \AA, 4 \mu \mathrm{m}, 250 \times 4,6 \mathrm{~mm}$ ) and a linear gradient from $80 \%$ to $50 \%$ of eluent $\mathrm{A}$ in $16 \mathrm{~min}$ with a flow rate of $1 \mathrm{~mL} / \mathrm{min}$. Low resolution (LR)-MS was performed on a Bruker maXis (UHR-TOF, Vienna, Austria) equipped with ESI ion source and Qq-TOF analyser or Bruker amaZon speed ETD supplied with ESI ion source and 3D ion trap. Sample centrifugation was done by Hettich Universal $30 \mathrm{RF}$ with Hettich rotor $141224 \times 3 g$.

In vitro and in vivo experiments were carried out with radiolabeled peptides with a purity of at least $95 \%$ ( $\gamma$-HPLC). Samples were $\gamma$-counted for 30 sec using an energy window of 104-170 keV (2480 Wizard ${ }^{2}$, PerkinElmer, Waltham, Mass., USA).

\subsection{Syntheses}

Synthesis of compound 3. The compound was prepared according to a published procedure ref. [22]. 2,3;4,5-Di-O-isopropylidene D-glucitol (1, $525 \mathrm{mg}, 2 \mathrm{mmol})$ and $\mathrm{Bu}_{2} \mathrm{SnO}(550 \mathrm{mg}, 2.2 \mathrm{mmol})$ were suspended in toluene $(20 \mathrm{~mL})$ and stirred at reflux with a Dean Stark for $24 \mathrm{~h}$. Tert-butyl 4-bromobutanoate $(2,888 \mathrm{mg}, 4 \mathrm{mmol})$ and tertrabutylammonium iodide ( $148 \mathrm{mg}, 0.4 \mathrm{mmol})$ were added to the solution and stirring at reflux was continued for $24 \mathrm{~h}$. The solvent was removed in vacuo and the crude product purified by chromatography on silicagel with ethyl acetate/hexane $(1: 4 \rightarrow 1: 2)$ to yield product 3 as a yellow oil $(250 \mathrm{mg}, 31 \%) .{ }^{1} \mathrm{H}-\mathrm{NMR}\left(\mathrm{CDCl}_{3}\right): \delta=4.10(\mathrm{dd}, 1 \mathrm{H}, J=5.7$ and $8.3 \mathrm{~Hz})$, 4.05-3.96 (m, 2H), 3.95-3.91 (m, 2H), 3.90-3.88 (m, 1H), 3.55-3.45 (m, 4H), $2.45(\mathrm{~d}, 1 \mathrm{H}, J=7.1 \mathrm{~Hz})$, $2.28(\mathrm{t}, 2 \mathrm{H}, J=7.3 \mathrm{~Hz}), 1.88-1.80(\mathrm{~m}, 2 \mathrm{H}), 1.41(\mathrm{~s}, 9 \mathrm{H}), 1.38(\mathrm{~s}, 3 \mathrm{H}), 1.382(\mathrm{~s}, 3 \mathrm{H}), 1.34(\mathrm{~s}, 3 \mathrm{H}), 1.30(\mathrm{~s}, 3 \mathrm{H})$ 
ppm; ${ }^{13} \mathrm{C}-\mathrm{NMR}\left(\mathrm{CDCl}_{3}\right): \delta=172.9,109.8,109.6,80.3,80.2,77.3,77.1,72.8,70.5,69.1,67.9,32.4,28.2$, 27.3, 26.9, 26.7, 25.4, 25.2 ppm; HR-MS: $\left[\mathrm{M}+\mathrm{Na}^{+}\right]^{+}=427.2299$, calcd for $\mathrm{C}_{20} \mathrm{H}_{36} \mathrm{O}_{8} \mathrm{Na}$ : 427.2308.

Synthesis of pentaol 4. Attempted deprotection of bis-acetonide 3 ( $404 \mathrm{mg}, 1 \mathrm{mmol})$ in aq. AcOH $(80 \%, 5 \mathrm{~mL})$ by stirring at rt overnight did not provide expected pentaol 4 but quantitative formation of a single new product which corresponded to a not further characterized mono-acetonide $(360 \mathrm{mg}$, quant.; LR-MS, $\left[\mathrm{M}+\mathrm{Na}^{+}\right]^{+}=387.4$, calcd for $\mathrm{C}_{17} \mathrm{H}_{32} \mathrm{O}_{8} \mathrm{Na}$ : 387.2). Upon standing at $\mathrm{rt}$ in $\mathrm{CHCl}_{3}$ (or $\mathrm{CH}_{2} \mathrm{Cl}_{2}$ ) the mono-acetonide intermediate disproportionated to a mixture of isomers consisting of bisand mono-acetonides (LR-MS) and fully deprotected pentaol 4 . The latter was isolated by evaporation of the solvent under reduced pressure and purification by flash chromatography on silicagel with $\mathrm{CH}_{2} \mathrm{Cl}_{2} / \mathrm{MeOH}(9: 1 \rightarrow 5: 1)$. The mixture of bis-and mono-acetonides was also isolated and subjected to an additional cycle of $\mathrm{CHCl}_{3}{ }^{-}$mediated isomerization to yield pentaol 4 as a pale yellow oil $(100 \mathrm{mg}$, total yield 33\% (2 cycles) from compound 3). LR-MS: $\left[\mathrm{M}+\mathrm{Na}^{+}\right]^{+}=347.16$, calcd for $\mathrm{C}_{14} \mathrm{H}_{28} \mathrm{O}_{8} \mathrm{Na}$ : 347.17. The compound was fully characterized by NMR as its pentaacetate 5 (see below).

Synthesis of pentaacetate 5. Pentaol $4(77 \mathrm{mg}, 0.24 \mathrm{mmol})$ was dissolved in $\mathrm{CH}_{2} \mathrm{Cl}_{2}(1 \mathrm{~mL})$ and acetic acid anhydride $(0.5 \mathrm{~mL})$ and pyridine $(0.3 \mathrm{~mL})$ were added. The solution was stirred at $\mathrm{rt}$ for $18 \mathrm{~h}$. Evaporation in vacuo and purification by flash chromatography on silicagel with $\mathrm{CH}_{2} \mathrm{Cl}_{2} / \mathrm{MeOH}$ $(9: 1 \rightarrow 5: 1)$ gave pentaacetate tBu-ester 5 as a colorless oil $(110 \mathrm{mg}, 96 \%) .{ }^{1} \mathrm{H}-\mathrm{NMR}\left(\mathrm{CDCl}_{3}\right): \delta=5.53$ $(\mathrm{dd}, 1 \mathrm{H}, J=7.1$ and $3.5 \mathrm{~Hz}), 5.40(\mathrm{dd}, 1 \mathrm{H}, J=7.6$ and $3.5 \mathrm{~Hz}), 5.12-5.02(\mathrm{~m}, 2 \mathrm{H}), 4.23(\mathrm{dd}, 1 \mathrm{H}, J=12.4$ and $3.3 \mathrm{~Hz}), 4.11(\mathrm{dd}, 1 \mathrm{H}, J=12.4$ and $5.3 \mathrm{~Hz}), 3.58(\mathrm{dd}, 1 \mathrm{H}, J=11.0$ and $4.6 \mathrm{~Hz}), 3.53-3.45(\mathrm{~m}, 2 \mathrm{H})$, 3.43-3.35 (m, 2H), 2.38-2.23 (m, 1H), $2.12(\mathrm{~s}, 3 \mathrm{H}), 2.07(\mathrm{~s}, 3 \mathrm{H}), 2.06(\mathrm{~s}, 3 \mathrm{H}), 2.05(\mathrm{~s}, 6 \mathrm{H}), 1.85-1.80(\mathrm{~m}$, 2H), $1.43(\mathrm{~s}, 9 \mathrm{H}) \mathrm{ppm} ;{ }^{13} \mathrm{C}-\mathrm{NMR}\left(\mathrm{CDCl}_{3}\right): \delta=172.8,170.6,170.3,170.0,169.9,80.1,71.0,70.7,68.9,68.8$, $68.7,68.5,61.7,32.2,28.2,25.1,21.0,20.91,20.86,20.8,20.7 \mathrm{ppm}$ (1 carbonyl signal not observed due to overlapping signals); LR-MS: $\left[\mathrm{M}+\mathrm{Na}^{+}\right]^{+}=557.29$, calcd for $\mathrm{C}_{24} \mathrm{H}_{38} \mathrm{O}_{13} \mathrm{Na}$ : 557.54.

Synthesis of carboxylic acid 6. Pentaacetate tertBu-ester $5(110 \mathrm{mg}, 0.21 \mathrm{mmol})$ was dissolved in $\mathrm{CH}_{2} \mathrm{Cl}_{2} / \mathrm{TFA}(3: 1,4 \mathrm{~mL})$ and stirred at $\mathrm{rt}$ for $18 \mathrm{~h}$. Evaporation of the volatile components under reduced pressure provided carboxylic acid 6 as a yellow oil $\left(98 \mathrm{mg}\right.$, quant.). ${ }^{1} \mathrm{H}-\mathrm{NMR}\left(\mathrm{CDCl}_{3}\right): \delta=5.54$ $(\mathrm{dd}, 1 \mathrm{H}, J=7.1$ and $3.6 \mathrm{~Hz}), 5.40(\mathrm{dd}, 1 \mathrm{H} J=7.4$ and $3.6 \mathrm{~Hz}), 5.10-5.07(\mathrm{~m}, 2 \mathrm{H}), 4.25(\mathrm{dd}, 1 \mathrm{H} \mathrm{J}=12.4$ and $3.2 \mathrm{~Hz}), 4.12(\mathrm{dd}, 1 \mathrm{H}, J=12.4$ and $5.6 \mathrm{~Hz}), 3.60(\mathrm{dd}, 1 \mathrm{H}, J=10.9$ and $4.6 \mathrm{~Hz}), 3.55-3.43(\mathrm{~m}, 3 \mathrm{H})$, 2.50-2.43 (m, 2H), $2.13(\mathrm{~s}, 3 \mathrm{H}), 2.074(\mathrm{~s}, 3 \mathrm{H}), 2.069(\mathrm{~s}, 3 \mathrm{H}), 2.066(\mathrm{~s}, 3 \mathrm{H}), 2.061(\mathrm{~s}, 3 \mathrm{H}), 1.96-1.86(\mathrm{~m}, 2 \mathrm{H})$ ppm; LR-MS: $\left[\mathrm{M}+\mathrm{Na}^{+}\right]^{+}=501.16$, calcd for $\mathrm{C}_{20} \mathrm{H}_{30} \mathrm{O}_{13} \mathrm{Na}$ : 501.16 .

Synthesis of compound 8. Pentaacetate $6(96 \mathrm{mg}, 0.2 \mathrm{mmol})$ was dissolved in $\mathrm{CH}_{2} \mathrm{Cl}_{2}(3 \mathrm{~mL})$ and Lys-derivative 7 [17] ( $77 \mathrm{mg}, 0.26 \mathrm{mmol}), \mathrm{BOP}(134 \mathrm{mg}, 0.3 \mathrm{mmol})$, and DIPEA ( $0.3 \mathrm{~mL}, 1 \mathrm{mmol})$ were added. The solution was stirred at $\mathrm{rt}$ for $2.5 \mathrm{~h}$. Evaporation under reduced pressure and purification of the crude product by flash chromatography on silicagel with EtOAc gave coupling product 8 as a pale yellow oil (140 mg, 92\%). LR-MS: $\left[\mathrm{M}+\mathrm{H}^{+}\right]^{+}=759.36$, calcd for $\mathrm{C}_{35} \mathrm{H}_{55} \mathrm{~N}_{2} \mathrm{O}_{16}$ : 759.38. As already reported [17], the formation of rotamers due to the presence of the trisubstituted $\mathrm{N}(\alpha)$ amine of the Lysine resulted in the duplication and/or broadening of NMR signals; thus, the compound was fully characterized after the Boc-deprotection (see compound 9 ).

Synthesis of pentaacetate 9. Compound $8(80 \mathrm{mg}, 0.11 \mathrm{mmol})$ was dissolved in $\mathrm{CH}_{2} \mathrm{Cl}_{2} / \mathrm{TFA}$ (3:1, $4 \mathrm{~mL}$ ) and kept at $\mathrm{rt}$ for $3 \mathrm{~h}$ after which time TLC indicated completed conversion. The solution was evaporated under reduced pressure, the residue was dissolved in $\mathrm{MeOH}(2 \mathrm{~mL})$, filtered through Celite $^{\mathrm{TM}}$ and dried in vacuo to provide the TFA salt of compound 9 as a colorless oil (75 $\left.\mathrm{mg}, 93 \%\right)$. ${ }^{1} \mathrm{H}-\mathrm{NMR}\left(\mathrm{MeOH}-\mathrm{d}_{4}\right.$; recorded after complete $\mathrm{H} / \mathrm{D}$ exchange): $\delta=5.51(\mathrm{dd}, 1 \mathrm{H}, J=4.0$ and $6.3 \mathrm{~Hz}), 5.41$ $(\mathrm{dd}, 1 \mathrm{H}, J=4.0$ and $6.9 \mathrm{~Hz}), 5.16-5.10(\mathrm{~m}, 2 \mathrm{H}), 5.08-5.03(\mathrm{~m}, 2 \mathrm{H}), 4.31(\mathrm{dd}, 1 \mathrm{H}, J=12.3$ and $3.4 \mathrm{~Hz}), 4.18$ $(\mathrm{dd}, 1 \mathrm{H}, J=7.0$ and $5.0 \mathrm{~Hz}), 4.12(\mathrm{dd}, 1 \mathrm{H}, J=12.3$ and $5.7 \mathrm{~Hz}), 4.02(\mathrm{t}, 2 \mathrm{H}, J=2.5 \mathrm{~Hz}), 3.87(\mathrm{~s}, 3 \mathrm{H}), 3.58$ $(\mathrm{dd}, 1 \mathrm{H}, J=11.0$ and $5.0 \mathrm{~Hz}), 3.54-3.40(\mathrm{~m}, 3 \mathrm{H}), 3.28(\mathrm{t}, 1 \mathrm{H}, J=2.5 \mathrm{~Hz}), 3.19(\mathrm{t}, 2 \mathrm{H}, J=6.9 \mathrm{~Hz}), 2.27$ $(\mathrm{t}, 2 \mathrm{H}, J=7.3 \mathrm{~Hz}), 2.17(\mathrm{~s}, 3 \mathrm{H}), 2.05(\mathrm{~s}, 3 \mathrm{H}), 2.04(\mathrm{~s}, 3 \mathrm{H}), 2.03(\mathrm{~s}, 3 \mathrm{H}), 2.02(\mathrm{~s}, 3 \mathrm{H}), 2.11-1.95(\mathrm{~m}, 2 \mathrm{H})$, $1.90-1.80(\mathrm{~m}, 2 \mathrm{H}), 1.62-1.50(\mathrm{~m}, 2 \mathrm{H}), 1.50-1.31(\mathrm{~m}, 2 \mathrm{H}) \mathrm{ppm} ;{ }^{13} \mathrm{C}-\mathrm{NMR}(\mathrm{MeOH}-\mathrm{d} 4): \delta=175.8,172.2$, 171.8, 171.59, 171.56, 171.5, $160.4(\mathrm{q}, \mathrm{JC}-\mathrm{F}=39 \mathrm{~Hz}), 116.9(\mathrm{q}, \mathrm{JC}-\mathrm{F}=277 \mathrm{~Hz}), 79.8,74.1,72.0,71.7,70.4$, 
70.2, 70.1, 69.8, 62.7, 59.9, 54.0, 39.6, 36.4, 33.7, 29.9, 29.8, 27.0, 22.9, 20.81, 20.80, 20.63, 20.62, 20.6 ppm; LR-MS: $\left[\mathrm{M}+\mathrm{H}^{+}\right]^{+}=659.33$, calcd for $\mathrm{C}_{30} \mathrm{H}_{47} \mathrm{~N}_{2} \mathrm{O}_{14}: 659.33$.

Synthesis of compound 10. Pentaacetate 9 (77 mg, $0.1 \mathrm{mmol})$ was dissolved in MeOH/THF (1:1, $1 \mathrm{~mL})$ and $\mathrm{NaOH}(1 \mathrm{M}, 2 \mathrm{~mL})$ was added. The solution was stirred at $\mathrm{rt}$ for $13 \mathrm{~h}$ and the $\mathrm{pH}$ was adjusted to $\mathrm{pH} 4$ by addition of $\mathrm{HCl}(1 \mathrm{M})$. The solution was concentrated under reduced pressure and the residue was triturated in dry isopropanol $(2 \mathrm{~mL})$. The salts were filtered off and the filtrate was evaporated in vacuo to provide compound 10 as a colorless oil $(39 \mathrm{mg}, 91 \%) .{ }^{1} \mathrm{H}-\mathrm{NMR}\left(\mathrm{MeOH}-\mathrm{d}_{4}\right.$, recorded after complete $\mathrm{H} / \mathrm{D}$ exchange): $\delta=3.89(\mathrm{dd}, 1 \mathrm{H}, J=16.6$ and $2.6 \mathrm{~Hz}), 3.81(\mathrm{dd}, 1 \mathrm{H}, J=16.6$ and $2.6 \mathrm{~Hz}), 3.81-3.77(\mathrm{~m}, 2 \mathrm{H}), 3.70(\mathrm{dd}, 1 \mathrm{H}, J=11.0$ and $3.3 \mathrm{~Hz}), 3.67-3.61(\mathrm{~m}, 2 \mathrm{H}), 3.598-3.53(\mathrm{~m}, 2 \mathrm{H})$, $3.52-3.34(\mathrm{~m}, 6 \mathrm{H}), 3.10(\mathrm{t}, 2 \mathrm{H}, J=6.5 \mathrm{~Hz}), 3.08(\mathrm{t}, 1 \mathrm{H}, J=2.5 \mathrm{~Hz}), 2.20(\mathrm{t}, 2 \mathrm{H}, J=7.3 \mathrm{~Hz}), 1.92-1.70(\mathrm{~m}$, $4 \mathrm{H}), 1.52-1.29(\mathrm{~m}, 4 \mathrm{H}) \mathrm{ppm} ;{ }^{13} \mathrm{C}-\mathrm{NMR}\left(\mathrm{MeOH}-\mathrm{d}_{4}\right): \delta=176.0,172.7,79.3,79.2,74.7,73.2,73.0,72.7$, $71.3,70.9,64.5,61.9,39.8,36.7,33.8,30.6,29.9,26.9,23.2$ ppm; LR-MS, $\left[\mathrm{M}+\mathrm{H}^{+}\right]^{+}=435.4$, calcd for $\mathrm{C}_{19} \mathrm{H}_{35} \mathrm{~N}_{2} \mathrm{O}_{9}$ : 435.23; LR-MS: [M + Li $\left.{ }^{+}\right]^{+}=441.4$, calcd for $\mathrm{C}_{34} \mathrm{H}_{47} \mathrm{~N}_{2} \mathrm{O}_{9} \mathrm{Li}: 441.24$.

Synthesis of azido peptide 11. The synthesis of azido peptide $\mathbf{1 1}$ has been previously described [23]. For manual solid phase peptide synthesis, Fmoc-protected amino acids (Fmoc-Gln(Trt)-OH, Fmoc-Trp(Boc)-OH, Fmoc-Ala-OH, Fmoc-Val-OH, Fmoc-Gly-OH, Fmoc-His(Trt)-OH, Fmoc-Leu-OH, Fmoc-Nle-OH) or azidoacetic acid ( 3 equiv.) were coupled to a Rink resin (scale: $0.025 \mathrm{mmol}$ ) in a syringe fitted with a polypropylene frit and a teflon tap in the presence of HATU (3 equiv.) and DIPEA (5 equiv.) in DMF for $2 \mathrm{~h}$. The completion of the reaction was verified by the Kaiser test and repeated if necessary. Elongation yields were determined by the UV-absorption measurement of the fluorenylmethylpiperidine adduct after treatment of the resin with $5 \mathrm{~mL}$ of a $20 \%$ piperidine/DMF solution $(3 \times 3 \mathrm{~min})$. Azido peptide 11 was cleaved from the resin and deprotected using a solution of trifluoroacetic acid, phenol, water and triisopropylsilane $(1 \mathrm{~mL} ; 92.5 / 2.5 / 2.5 / 2.5 \%)$ as a cleavage cocktail at $\mathrm{rt}$ for $2 \mathrm{~h}$. After precipitation in ice-cold diethyl ether, the crude peptide was recovered by centrifugation and washed twice with cold diethyl ether. The precipitate was dissolved in water (5-10 mg/mL), lyophilized and analyzed by HPLC and MS: white fluffy powder ( $20 \mathrm{mg}, 65 \%)$, purity according to HPLC: $>80 \%$, LR-MS: $\left[\mathrm{M}+\mathrm{H}^{+}\right]^{+}=1219.32$, calcd for $\mathrm{C}_{55} \mathrm{H}_{84} \mathrm{~N}_{19} \mathrm{O}_{13}: 1219.40$.

Synthesis of glycated peptide BBN-12. Crude azido peptide 11 (13 mg; purity: ca. $80 \% ; 8 \mu \mathrm{mol}$ ) was dissolved in $20 \% \mathrm{CH}_{3} \mathrm{CN} / \mathrm{H}_{2} \mathrm{O}(1 \mathrm{~mL})$ and $\mathrm{Cu}(\mathrm{OAc})_{2}$ (1 equiv.), sodium ascorbate (2 equiv.), and alkyne-sorbitol building block 10 ( $5.5 \mathrm{mg}, 1.5$ equiv.) were added. The reaction mixture was stirred at $\mathrm{rt}$ for $13 \mathrm{~h}$, filtered, and purified by semi-preparative HPLC (gradient: $23-35 \% 0.1 \%$ TFA in $\mathrm{CH}_{3} \mathrm{CN}$ within $15 \mathrm{~min}$; flow $4 \mathrm{~mL} / \mathrm{min}, \lambda=215 \mathrm{~nm}$ ). After liophylization, peptide BBN-12 was isolated as a white fluffy powder $(4 \mathrm{mg}, 30 \%)$, purity according to HPLC: $>95 \%$, LR-MS: $\left[\mathrm{M}+\mathrm{H}^{+}\right]^{+}=1652.99$, calcd for $\mathrm{C}_{74} \mathrm{H}_{118} \mathrm{~N}_{21} \mathrm{O}_{22}: 1652.876$.

\subsection{Radiolabeling}

\subsection{1. $\left[{ }^{99 \mathrm{~m}} \mathrm{Tc}\right]\left[\mathrm{Tc}(\mathrm{CO})_{3}\left(\mathrm{H}_{2} \mathrm{O}\right)_{3}\right]^{+}$}

Technetium was provided in form of $\left[{ }^{99 \mathrm{~m}} \mathrm{Tc}\right]\left[\mathrm{TcO}_{4}\right]^{-}$from a ${ }^{99} \mathrm{Mo} /{ }^{99 m} \mathrm{Tc}$ generator. The generator was eluted at least $24 \mathrm{~h}$ before the elution for the labeling in order to obtain sufficient specific activity of the pertechnetate. The eluate contained $1-2 \mathrm{GBq} / \mathrm{mL}$ in $0.9 \%$ saline. $\left[{ }^{99 \mathrm{~m}} \mathrm{Tc}\right]\left[\mathrm{Tc}(\mathrm{CO})_{3}\left(\mathrm{H}_{2} \mathrm{O}\right)_{3}\right]^{+}$was prepared by the procedures described in the instruction leaflet of the CRS kit. In brief, 1.0-1.2 $\mathrm{mL}$ of $\left[{ }^{99} \mathrm{~m} \mathrm{Tc}\right]\left[\mathrm{TcO}_{4}\right]^{-}$solution was added to the CRS kit for tricarbonyl and subsequently heated for $30 \mathrm{~min}$ at $100{ }^{\circ} \mathrm{C}$. Afterwards, the solution $(\mathrm{pH}>10)$ was cooled to room temperature and neutralized to pH 7 with an acidified phosphate buffer (1:2 mix of $1 \mathrm{M} \mathrm{Na}_{2} \mathrm{HPO}_{4} / \mathrm{NaH}_{2} \mathrm{PO}_{4}(1: 1): 1 \mathrm{M} \mathrm{HCl}$; $\mathrm{pH} 1.5$, $50 \mu \mathrm{L})$. The radiochemical yield and purity of $\left[{ }^{99 \mathrm{~m}} \mathrm{Tc}\right]\left[\mathrm{Tc}(\mathrm{CO})_{3}\left(\mathrm{H}_{2} \mathrm{O}\right)_{3}\right]^{+}$was determined by $\gamma-\mathrm{HPLC}$ $\left(\mathrm{R}_{\mathrm{t}}=10.35 \mathrm{~min}\right.$ ) and $\gamma$-TLC (for $\mathrm{R}_{\mathrm{f}}$ values see SM, Figures $\mathrm{S} 12-\mathrm{S} 14$ ) and was $>98 \%$. 


\subsection{2. $\left[{ }^{99 \mathrm{~m}} \mathrm{Tc}\right]\left[\mathrm{Tc}(\mathrm{CO})_{3}(\mathrm{~L})\right](\mathrm{L}=\mathbf{1 2}, \mathbf{1 3})$}

$20 \mu \mathrm{L}$ of the respective stock solution of the peptide conjugates in water (compound BBN-12 or BBN-13; $1 \mathrm{mM}, 20 \mathrm{nmol}$ ) were added to $180 \mu \mathrm{L}$ of ${ }^{99 \mathrm{~m}}$ Tc-tricarbonyl solution ( 150 MBq, $0.1 \mathrm{mM}$ final peptide concentration). The reaction was completed either by heating at $100{ }^{\circ} \mathrm{C}$ for $30 \mathrm{~min}$ in a heating block or at $120^{\circ} \mathrm{C}$ for $5 \mathrm{~min}$ in a microwave reactor. The identity and radiochemical purity of $\left[{ }^{99 \mathrm{~m}} \mathrm{Tc}\right]\left[\mathrm{Tc}(\mathrm{CO})_{3}(\mathrm{~L})\right](\mathrm{L}=\mathbf{1 2}, \mathbf{1 3})$ was determined by $\gamma$-HPLC $\left(\mathrm{R}_{\mathrm{t}([99 \mathrm{mTc}][\mathrm{Tc}(\mathrm{CO}) 3(13)])}=13.05 \mathrm{~min}\right.$, $\mathrm{R}_{\mathrm{t}([99 \mathrm{mTc}[\mathrm{Tc}(\mathrm{CO}) 3(12)])}=11.52 \mathrm{~min}$; see SM, Figures S12 and S13) and $\gamma$-TLC (for $\mathrm{R}_{\mathrm{f}}$ values see Table 1 and SM, Figure S16) and was at least $95 \%$.

\subsection{3. $\left[{ }^{\mathrm{nat}} \operatorname{Re}(\mathrm{CO})_{3}(\mathrm{~L})\right](\mathrm{L}=\mathbf{1 2}, \mathbf{1 3})$}

$\left[{ }^{\text {nat }} \operatorname{Re}(\mathrm{CO})_{3}(\mathrm{~L})\right](\mathrm{L}=\mathbf{1 2}, 13)$ were prepared by mixing $20 \mu \mathrm{L}$ of aqueous stock solutions containing peptide BBN-12 or BBN-13 (1 equiv, $1 \mathrm{mM}$ ) with $30 \mu \mathrm{L}$ of $\left[\mathrm{N}(\mathrm{Et})_{4}\right]_{2}\left[\operatorname{Re}(\mathrm{CO})_{3} \mathrm{Br}_{3}\right](1.5$ equiv, $1 \mathrm{mM})$ in water [23]. The reaction was heated at $100^{\circ} \mathrm{C}$ for $1 \mathrm{~h}$. The products were purified by HPLC and analyzed by LR-MS. [ $\left.{ }^{\text {nat }} \operatorname{Re}(\mathrm{CO})_{3}(13)\right]$ : $\mathrm{R}_{\mathrm{t}}=12.58 \mathrm{~min}$ (see SM, Figure S12); LR-MS: $\left[\mathrm{M}+\mathrm{H}^{+}\right]^{+}=1714.72$ (calcd for $\mathrm{C}_{69} \mathrm{H}_{100} \mathrm{~N}_{21} \mathrm{O}_{19}$ Re: 1714.71; see SM, S14). [ $\left.{ }^{\text {nat }} \operatorname{Re}(\mathrm{CO})_{3}(12)\right]: \mathrm{R}_{\mathrm{t}}=11.47 \mathrm{~min}$ (see SM, Figure S13); LR-MS: $\left[\mathrm{M}+\mathrm{H}^{+}\right]^{+}=1922.80$ (calcd for $\mathrm{C}_{77} \mathrm{H}_{116} \mathrm{~N}_{21} \mathrm{O}_{25}$ Re: 1922.80; see SM, Figure S15).

\subsection{TLC}

The purity of the ${ }^{99 \mathrm{~m}} \mathrm{Tc}-$ labeled peptides was additionally confirmed by thin-layer chromatography (TLC) using silica gel $60 \mathrm{~F}_{254}$ aluminum plates (Merck, Darmstadt, Germany), as stationary phase (strips height $10 \mathrm{~cm}$ with $8 \mathrm{~cm}$ between application point and solvent front). A mixture 95.5:0.5 of MeOH: $\mathrm{HCl} 6$ $M$ was used as mobile phase. In a typical assay, $2 \mu \mathrm{L}$ drops of freshly prepared [ $\left.{ }^{99 \mathrm{~m}} \mathrm{Tc}\right]\left[\mathrm{Tc}(\mathrm{CO})_{3}(\mathbf{1 3})\right]$ or its glycated derivative $\left[{ }^{99 \mathrm{~m}} \mathrm{Tc}\right]\left[\mathrm{Tc}(\mathrm{CO})_{3}(\mathbf{1 2})\right]$ were spotted on the plates. After drying the spots, the plate was developed and subsequently dried. Likewise, samples of $\left[{ }^{99 \mathrm{~m}} \mathrm{Tc}_{\mathrm{Tc}} \mathrm{Tc}_{4}{ }^{-}\right.$and $\left[{ }^{99 \mathrm{~m}} \mathrm{Tc}\right]\left[\mathrm{Tc}(\mathrm{CO})_{3}\left(\mathrm{H}_{2} \mathrm{O}\right)_{3}\right]^{+}$ were analyzed in order to identify the ${ }^{99 \mathrm{~m}}$ Tc-radiolabeled peptides. The readout of the radio-TLC was performed using a Canberra-Packard Instant Imager (Packard Instrument Company, Meriden, USA) using Imager software (version 2.05 for Windows 95). Regions of interests (ROIs) were defined for all radioactivity peaks found along the plate while start and front parameters of the TLC-plate were given in the software. Consequently, $\mathrm{R}_{\mathrm{f}}$ values were determined and the radiochemical purity of the radiotracers calculated as the percentage of the counts of $\left[{ }^{99 \mathrm{~m}} \mathrm{Tc}\right]\left[\mathrm{Tc}(\mathrm{CO})_{3}(\mathbf{1 3})\right](n=3$ in duplicates) or $\left[{ }^{99 \mathrm{~m}} \mathrm{Tc}\right]\left[\mathrm{Tc}(\mathrm{CO})_{3}(\mathbf{1 2})\right](n=2$ in duplicates) divided by the sum of counts in all ROIs.

\section{5. $\log D$}

The lipophilicities $(\operatorname{LogD})$ of $\left[{ }^{99 \mathrm{~m}} \mathrm{Tc}\right]\left[\mathrm{Tc}(\mathrm{CO})_{3}(\mathrm{~L})\right](\mathrm{L}=\mathbf{1 2}, 13)$ were determined by their partition coefficient between n-octanol and PBS (pH 7.4) utilizing the "shake-flask method" [25,26]. PBS and $\mathrm{n}$-octanol were shaken overnight to saturate each phase. After separation of the layers by gravity, equal volumes $(500 \mu \mathrm{L})$ of each layer were taken and transferred into an Eppendorf tube and $5 \mu \mathrm{L}$ $(\sim 45 \mathrm{kBq})$ of the radiolabeled peptide solution were added to the PBS/n-octanol mixture. The resulting solutions were mixed in a shaker at room temperature for $20 \mathrm{~min}$ and centrifuged at $3000 \mathrm{rpm}$ for $10 \mathrm{~min}$. Aliquots of $300 \mu \mathrm{L}$ were removed from the octanol and PBS phases and the radioactivity was measured in the $\gamma$-counter ( $n=3$ in triplicates). The lipophilicity was calculated as the log value of the average ratio between the radioactivity in the organic fraction (octanol) and the PBS fraction from the samples.

\subsection{In Vitro Evaluation}

\subsubsection{General Methods}

Cell culture reagents were purchased from Thermo Fisher Scientific (Vienna, Austria) or Sigma-Aldrich (Vienna, Austria). Human prostate adenocarcinoma cells (PC-3) were purchased 
from ATCC and cultivated in RPMI-1640 medium supplemented with 10\% heat-inactivated fetal bovine serum (FBS), $2 \mathrm{mM}$ L-glutamine, $100 \mathrm{units} / \mathrm{mL}$ penicillin and $100 \mu \mathrm{g} / \mathrm{mL}$ streptomycin under humidified atmosphere $\left(37^{\circ} \mathrm{C}, 5 \% \mathrm{CO}_{2}\right)$ until minimum $80 \%$ at confluence. In order to determine the number of cells for each experiment, three extra wells were seeded for parallel cell counting using the Neubauer chamber (Ratiomed) and Trypan Blue solution, $0.4 \%$ (Gibco ${ }^{\circledR \circledR}$ ). Percentage of applied dose was normalized to $10^{6}$ cells/well.

\subsubsection{Internalization Studies}

Internalization studies were performed as previously published [23]. In brief, approximately $10^{6}$ PC-3 cells were seeded in 1\% FBS RPMI-medium (RPMI-1640 medium containing 1\% FBS, $2 \mathrm{mM}$ L-glutamine, $100 \mathrm{units} / \mathrm{mL}$ penicillin and $100 \mu \mathrm{g} / \mathrm{mL}$ streptomycin) in 6-well plates on the day before the experiment and incubated overnight in humidified incubator $\left(37^{\circ} \mathrm{C}, 5 \% \mathrm{CO}_{2}\right)$. Approx. one hour before the experiment, the medium was replaced with $1.3 \mathrm{~mL}$ fresh $1 \%$ FBS RPMI-medium. Subsequently, $100 \mu \mathrm{L}$ of radiolabeled peptide $\left[{ }^{99 \mathrm{~m}} \mathrm{Tc}\right]\left[\mathrm{Tc}(\mathrm{CO}){ }_{3}(\mathrm{~L})\right](\mathrm{L}=\mathbf{1 2}, \mathbf{1 3} ; 0.25 \mathrm{pmol} ; 1.0 \mathrm{kBq})$ were added to each well and cells were incubated for different time points (10, 60, and $120 \mathrm{~min})$. Non-specific receptor binding was determined by incubating the cells with the radiotracers and 1000 -fold excess of natural bombesin ( $250 \mathrm{pmol} ; 100 \mu \mathrm{L}$ per well) as the receptor blocking agent. After the respective incubation time, the supernatant was collected and the cells were washed twice with $1 \mathrm{~mL}$ ice-cold DPBS (Dulbecco's phosphate-buffered saline). The combined fractions represent the unbound radiopeptide. The receptor-bound radioactivity was obtained by incubating the cells twice for $5 \mathrm{~min}$ with an ice-cold acidic glycine solution (100 mM NaCl, $50 \mathrm{mM}$ glycine, $\mathrm{pH} 2.8 ; 1 \mathrm{~mL})$ on ice followed by removal of the supernatant. Finally, the internalized fraction was collected after cell lysis using $1 \mathrm{M} \mathrm{NaOH}\left(1 \mathrm{~mL} ; 10 \mathrm{~min} ; 37^{\circ} \mathrm{C}, 5 \% \mathrm{CO}_{2}\right)$ and the wells containing the cell lysate were washed twice with $\mathrm{NaOH}(1 \mathrm{M}, 1 \mathrm{~mL})$. Standards of the radiolabeled peptides $\left[{ }^{99 \mathrm{~m}} \mathrm{Tc}\right]\left[\mathrm{Tc}(\mathrm{CO})_{3}(\mathrm{~L})\right]$ ( $\mathrm{L}=12$, 13; per well: $100 \mu \mathrm{L} ; 0.25 \mathrm{pmol} ; 1.0 \mathrm{kBq}$ ) for determination of the applied dose were prepared in triplicate. All fractions were measured in a $\gamma$-counter and calculated as percentage of the applied dose ( $n=2-3$ in triplicate).

\subsubsection{Receptor Saturation Assay}

Receptor binding assays were performed as previously published [23]. PC-3 cells were prepared in 6-well plates as described above for the internalization experiments. Approx. one hour before the experiment, the medium was replaced with $0.8 \mathrm{~mL}$ fresh $1 \%$ FBS RPMI-medium. PC-3 cells were kept on ice for $30 \mathrm{~min}$ to stop receptor internalization processes prior to the start of the experiment. Afterwards, the cells were incubated at $4{ }^{\circ} \mathrm{C}$ with increasing concentration $(1,5,10,25,50,75$, and $100 \mathrm{nM}$ in $\mathrm{NaCl} ; 100 \mu \mathrm{L} /$ well, $5-600 \mathrm{kBq})$ of the radiolabeled peptides [99m $\mathrm{Tc}]\left[\mathrm{Tc}(\mathrm{CO})_{3}(\mathrm{~L})\right](\mathrm{L}=12,13)$ to allow receptor saturation. Non-specific receptor binding was determined using an excess of natural bombesin $(2.5 \mu \mathrm{M} /$ well for concentrations of the radiopeptide $<10 \mathrm{nM}$, and $10 \mu \mathrm{M} /$ well for higher concentrations). After incubation at $4{ }^{\circ} \mathrm{C}$ for $2 \mathrm{~h}$, the supernatant was collected and the cells were washed twice with $1 \mathrm{~mL}$ of ice-cold DPBS. The combined fractions represent the unbound radiopeptide. To determine the cell-bound fraction, the cells were lysed with $1 \mathrm{M} \mathrm{NaOH}\left(1 \mathrm{~mL} ; 10 \mathrm{~min} ; 37^{\circ} \mathrm{C}, 5 \% \mathrm{CO}_{2}\right)$ and the wells were washed twice with $1 \mathrm{M} \mathrm{NaOH}(1 \mathrm{~mL})$. The obtained fractions were measured in a $\gamma$-counter. Dissociation constants $\left(\mathrm{K}_{\mathrm{d}}\right)$ and maximum receptor occupancy $\left(\mathrm{B}_{\max }\right)$ were calculated from the data for specific binding with nonlinear regression using GraphPad Prism 7 ( $n=2-3$ in triplicate).

\subsection{In Vivo Evaluation}

\section{Biodistribution Experiments}

All animals were treated according to the European Union rules on animal care. Animal experiments were approved by the Austrian Ministry of Sciences (BMBWF-66.009/0122-V/3b/2019). Approximately $5 \times 10^{6} \mathrm{PC}-3$ cells in $100 \mu \mathrm{L}$ serum-free medium were subcutaneously injected into 
flanks of 8-week-old, female, athymic mice (Fox-1 ${ }^{\text {nu }}$, Charles River Laboratories). Xenografts were allowed to grow for 16 days (approx. size: $250 \mathrm{~mm}^{3}$ ) and mice were intravenously injected via the tail vein with $0.1 \mu \mathrm{M}$ radiolabeled peptide (10 pmol, $\sim 42 \mathrm{kBq}, 100 \mu \mathrm{L}$ physiological saline) alone (baseline experiments) or co-injected with 2000-fold excess BBN(1-14) (20 nmol; blocking experiments). One hour p.i. of the radiotracers, mice were sacrificed and organs, tumor and blood were removed. Radioactivity in organs and tissues was quantified using a $\gamma$-counter (2480 Wizard ${ }^{2}$, PerkinElmer). Organs and tissues were wet-weighted and percentage of injected dose per gram was calculated (\% ID/g). Statistical analysis (2-way ANOVA) was performed by GraphPad Prism.

\section{Conclusions}

We have applied the "Click-to-Chelate" methodology to the efficient synthesis of a ${ }^{99 \mathrm{~m}}$ Tc-tricarbonyl labeled tumor-targeting BBN conjugate that contains sorbitol as an acyclic, reduced carbohydrate modifier for increasing the hydrophilicity of the radiopeptide and, as a result, to promote renal elimination in vivo. Indeed, addition of sorbitol to the ${ }^{99 \mathrm{~m}} \mathrm{Tc}$-labeled BBN derivative increased its hydrophilicity $(\log \mathrm{D})$ by $0.7 \log$ units in comparison to a non-glycated reference compound. However, both compounds showed comparable pharmacokinetic profiles in vivo with regards to rate and route of excretion. For example, unspecific uptake of the radiotracer in the excretory organs kidneys and liver was found almost identical for both compounds despite the increased hydrophilicity of the glycated peptide. This puzzling result might be explained by the inherent properties of the studied peptide, $\left[\mathrm{Nle}^{14}\right] \mathrm{BBN}(7-14)$, and/or its metabolites. Indeed, low unspecific uptake in the liver has been reported for other related agonistic BBN derivatives radiolabeled with the ${ }^{99 \mathrm{~m}} \mathrm{Tc}$-tricarbonyl core [28]. However, this phenomenon will need to be verified with other peptides or (bio)molecules of interest for nuclear medicine. Further investigations in this direction are currently ongoing and will be reported in due time.

The herein reported sorbitol-containing lysine derivative 10 (Scheme 1) represents a promising general alkyne precursor for the "Click-to-Chelate" approach which might proof useful for overcoming the often stated but yet unresolved issue of the increased lipophilicity of radiotracers resulting from the radiolabeling with the ${ }^{99 \mathrm{~m}}$ Tc-tricarbonyl core [6].

Supplementary Materials: The following are available online at http://www.mdpi.com/1420-3049/25/11/2680/s1, ${ }^{1} \mathrm{H} /{ }^{13} \mathrm{C}$-NMR and MS data of small molecules, UV-HPLC chromatograms and MS data of peptide conjugates, and $\gamma$-HPLC chromatograms as well as $\gamma$-TLC of ${ }^{99 \mathrm{~m}} \mathrm{Tc}$-labeled peptide conjugates are available on-line.

Author Contributions: T.L.M. designed the study and synthesized compound $\mathbf{1 0}$ and peptides BBN-12 and BBN-13. C.G. conducted the radiolabeling of peptide conjugates, performed in vitro experiments and $\log \mathrm{D}$ determination, and assisted in in vivo experiments. T.B. wrote the animal ethic and had the lead for the animal studies. K.B. conducted in part the cell experiments and N.J. assisted. J.C. and M.B. assisted in the radiolabeling experiments and quality control of radiolabeled peptide conjugates. N.B.-I. conducted the TLC analysis. C.G., T.L.M, J.C., N.B.-I. and T.B. wrote the manuscript. M.H. and M.M. contributed to the interpretation of the data and revised the manuscript. All authors have read and agreed to the published version of the manuscript.

Funding: This research received no external funding.

Acknowledgments: We thank R. Schibli (ETH Zurich/PSI Villigen) for providing CRS kits, the Preclinical Imaging Laboratory (Medical University of Vienna) for technical support with animal experiments, and the staff of the nuclear medicine department (Vienna General Hospital) for providing ${ }^{99 \mathrm{~m}} \mathrm{Tc}-\mathrm{eluates}$. Open Access Funding was provided by the University of Vienna.

Conflicts of Interest: The authors declare no conflict of interest.

\section{References}

1. Rösch, F.; Baum, R.P. Generator-based PET radiopharmaceuticals for molecular imaging of tumours: On the way to THERANOSTICS. Dalt. Trans. 2011, 40, 6104-6111. [CrossRef] [PubMed]

2. Brandt, M.; Cardinale, J.; Aulsebrook, M.L.; Gasser, G.; Mindt, T.L. An Overview of PET Radiochemistry, Part 2: Radiometals. J. Nucl. Med. 2018, 59, 1500-1506. [CrossRef] [PubMed] 
3. García-Garayoa, E.; Schibli, R.; Schubiger, A.P. Peptides radiolabeled with Re-186/188 and Tc-99m as potential diagnostic and therapeutic agents. Nucl. Sci. Tech. 2007, 18, 88-100. [CrossRef]

4. Boschi, A.; Uccelli, L.; Martini, P. A picture of modern Tc-99m radiopharmaceuticals: Production, chemistry, and applications in molecular imaging. Appl. Sci. 2019, 9, 2526. [CrossRef]

5. Alberto, R.; Ortner, K.; Wheatley, N.; Schibli, R.; Schubiger, A.P. Synthesis and properties of boranocarbonate: A convenient in situ $\mathrm{CO}$ source for the aqueous preparation of $\left[{ }^{99 \mathrm{~m}} \mathrm{Tc}\left(\mathrm{OH}_{2}\right)_{3}(\mathrm{CO})_{3}\right]^{+}$. J. Am. Chem. Soc. 2001, 123, 3135-3136. [CrossRef] [PubMed]

6. Kluba, C.A.; Mindt, T.L. Click-to-Chelate: Development of technetium and rhenium-tricarbonyl labeled radiopharmaceuticals. Molecules 2013, 18, 3206-3226. [CrossRef] [PubMed]

7. Kasten, B.B.; Ma, X.; Liu, H.; Hayes, T.R.; Barnes, C.L.; Qi, S.; Cheng, K.; Bottorff, S.C.; Slocumb, W.S.; Wang, J.; et al. Clickable, hydrophilic ligand for fac- $\left[\mathrm{MI}(\mathrm{CO})_{3}\right]+\left(\mathrm{M}=\mathrm{Re} /{ }^{99 \mathrm{~m}} \mathrm{Tc}\right)$ applied in an S-functionalized $\alpha-\mathrm{MSH}$ peptide. Bioconjug. Chem. 2014, 25, 579-592. [CrossRef]

8. García-Garayoa, E.; Schweinsberg, C.; Maes, V.; Brans, L.; Bläuenstein, P.; Tourwé, D.A.; Schibli, R.; Schubiger, A.P. Influence of the molecular charge on the biodistribution of bombesin analogues labeled with the $\left[{ }^{99 \mathrm{~m}} \mathrm{Tc}(\mathrm{CO})_{3}\right]$-core. Bioconjug. Chem. 2008, 19, 2409-2416. [CrossRef]

9. Mindt, T.L.; Schweinsberg, C.; Brans, L.; Hagenbach, A.; Abram, U.; Tourwé, D.; García-Garayoa, E.; Schibli, R. A click approach to structurally diverse conjugates containing a central di-1,2,3-triazole metal chelate. Chem. Med. Chem. 2009. [CrossRef]

10. Däpp, S.; García-Garayoa, E.; Maes, V.; Brans, L.; Tourwé, D.A.; Müller, C.; Schibli, R. PEGylation of 99m Tc-labeled bombesin analogues improves their pharmacokinetic properties. Nucl. Med. Biol. 2011, 38, 997-1009. [CrossRef]

11. Valverde, I.E.; Vomstein, S.; Fischer, C.A.; Mascarin, A.; Mindt, T.L. Probing the backbone function of tumor targeting peptides by an amide-to-triazole substitution strategy. J. Med. Chem. 2015. [CrossRef] [PubMed]

12. Moradi, S.V.; Hussein, W.M.; Varamini, P.; Simerska, P.; Toth, I. Glycosylation, an effective synthetic strategy to improve the bioavailability of therapeutic peptides. Chem. Sci. 2016, 7, 2492-2500. [CrossRef] [PubMed]

13. Schottelius, M.; Laufer, B.; Kessler, H.; Wester, H.J. Ligands for mapping $\alpha \mathrm{v} \beta 3$-integrin expression in vivo. Acc. Chem. Res. 2009, 42, 969-980. [CrossRef] [PubMed]

14. Mindt, T.L.; Struthers, H.; Brans, L.; Anguelov, T.; Schweinsberg, C.; Maes, V.; Tourwe, D.; Schibli, R. “Click to chelate": Synthesis and installation of metal chelates into biomolecules in a single step. J. Am. Chem. Soc. 2006, 128, 15096-15097. [CrossRef]

15. Rostovtsev, V.V.; Green, L.G.; Fokin, V.V.; Sharpless, K.B. A stepwise huisgen cycloaddition process: Copper(I)-catalyzed regioselective "ligation" of azides and terminal alkynes. Angew. Chem. Int. Ed. 2002, 41, 2596-2599. [CrossRef]

16. Tornøe, C.W.; Christensen, C.; Meldal, M. Peptidotriazoles on solid phase: [1,2,3]-triazoles by regiospecific copper(I)-catalyzed 1,3-dipolar cycloadditions of terminal alkynes to azides. J. Org. Chem. 2002, 67, 3057-3064. [CrossRef]

17. Mindt, T.L.; Struthers, H.; Spingler, B.; Brans, L.; Tourwé, D.; García-Garayoa, E.; Schibli, R. Molecular assembly of multifunctional ${ }^{99 \mathrm{~m}}$ Tc radiopharmaceuticals using "clickable" amino acid derivatives. Chem. Med. Chem. 2010, 5, 2026-2038. [CrossRef]

18. Römhild, K.; Fischer, C.A.; Mindt, T.L. Glycated 99mTc-tricarbonyl-labeled peptide conjugates for tumor targeting by "click-to-chelate". Chem. Med. Chem. 2017, 12, 66-74. [CrossRef]

19. Rangger, C.; Haubner, R. Radiolabelled peptides for positron emission tomography and endoradiotherapy in oncology. Pharmaceuticals 2020, 13, 22. [CrossRef]

20. Weinstein, E.A.; Ordonez, A.A.; DeMarco, V.P.; Murawski, A.M.; Pokkali, S.; MacDonald, E.M.; Klunk, M.; Mease, R.C.; Pomper, M.G.; Jain, S.K. Imaging enterobacteriaceae infection in vivo with ${ }^{18}$ F-fluorodeoxysorbitol positron emission tomography. Sci. Transl. Med. 2014, 6, 259ra146. [CrossRef]

21. Leamon, C.P.; Reddy, J.A.; Klein, P.J.; Vlahov, I.R.; Dorton, R.; Bloomfield, A.; Nelson, M.; Westrick, E.; Parker, N.; Bruna, K.; et al. Reducing undesirable hepatic clearance of a tumor-targeted vinca alkaloid via novel saccharopeptidic modifications. J. Pharm. Exp. 2011, 336, 336-343. [CrossRef]

22. Jagadeesh, Y.; Reddy, J.S.; Rao, V.B.; Swarnalatha, L.J. Total synthesis of (-)-codonopsinol and (+)-2-epi codonopsinol via acid catalyzed amido cyclisation. Tetrahedron 2010, 66, 1202-1207. [CrossRef]

23. Kluba, C.A.; Bauman, A.; Valverde, I.E.; Vomstein, S.; Mindt, T.L. Dual-targeting conjugates designed to improve the efficacy of radiolabeled peptides. Org. Biomol. Chem. 2012, 10, 7594-7602. [CrossRef] 
24. Alberto, R.; Egli, A.; Abram, U.; Hegetschweiler, K.; Gramlich, V.; Schubiger, A.P. Synthesis and reactivity of $\left[\mathrm{NEt}_{4}\right]_{2}\left[\operatorname{ReBr}_{3}(\mathrm{CO})_{3}\right]$. Formation and structural characterization of the clusters $\left[\mathrm{NEt}_{4}\right]\left[\operatorname{Re}_{3}(\mu 3-\mathrm{OH})(\mu-\mathrm{OH})_{3}(\mathrm{CO})_{9}\right]$ and $\left[\mathrm{NEt}_{4}\right]\left[\operatorname{Re}_{2}(\mu-\mathrm{OH})_{3}(\mathrm{CO})_{6}\right]$ by alkaline titration. J. Chem. Soc. Dalt. Trans. 1994, 2815-2820. [CrossRef]

25. Vraka, C.; Nics, L.; Wagner, K.H.; Hacker, M.; Wadsak, W.; Mitterhauser, M. LogP, a yesterday's value? Nucl. Med. Biol. 2017, 50,1-10. [CrossRef]

26. OECD. Test No. 117: Partition Coefficient (n-Octanol/Water), HPLCMethod; OECD publishing: Paris, France, 2004. [CrossRef]

27. Fischer, C.A.; Vomstein, S.; Mindt, T.L. A bombesin-shepherdin radioconjugate designed for combined extraand intracellular targeting. Pharmaceuticals 2014. [CrossRef]

28. Schweinsberg, C.; Maes, V.; Brans, L.; Bläuenstein, P.; Tourwé, D.A.; Schubiger, A.P.; Schibli, R.; García-Garayoa, E. Novel glycated $\left[{ }^{99 \mathrm{~m}} \mathrm{Tc}(\mathrm{CO})_{3}\right]$-labeled bombesin analogues for improved targeting of gastrin-releasing peptide receptor-positive tumors. Bioconjug. Chem. 2008, 19, 2432-2439. [CrossRef]

Sample Availability: Samples of the compounds are not available from the authors.

(C) 2020 by the authors. Licensee MDPI, Basel, Switzerland. This article is an open access article distributed under the terms and conditions of the Creative Commons Attribution (CC BY) license (http://creativecommons.org/licenses/by/4.0/). 